\title{
Mehmet Refik Fenmen'in Aynştayn Nazariyyesi: Mekân Zaman ve Kütle Mefhumlarının Tebeddülü Adlı Eseri (Latin Harfli Metin ve Sözlük)
}

\section{Einstein's Theory and Conceptual Transformation of Time, Space and Mass by Mehmet Refik Fenmen (Text in Latin Alphabet and Glossary)}

\author{
Yusuf Akçay ${ }^{1}$ D
}

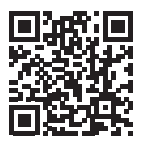

'Dr., İstanbul, Türkiye

ORCID:Y.A. 0000-0001-7876-3938

Sorumlu yazar/Corresponding author: Yusuf Akçay,

İstanbul, Türkiye

E-posta/E-mail: dryusufakcay@hotmail.com

Başvuru/Submitted: 03.12 .2019

Revizyon Talebi/Revision Requested:

24.12.2019

Son Revizyon/Last Revision Received:

08.05.2020

Kabul/Accepted: 10.05 .2020

Online Yayın/Published Online: 03.07.2020

Atıf/Citation: Akçay, Yusuf." "Mehmet Refik Fenmen'in Aynştayn Nazariyyesi: Mekân Zaman ve Kütle Mefhumlarının Tebeddülü adlı Eseri (Latin Harfli Metin ve Sözlük)." Osmanlı Bilimi Arastırmaları 21, 2 (2020): 369-398. https://doi.org/10.26650/oba.654466

\section{öz}

Aynştayn Nazariyyesi: Mekân, Zaman ve Kütle Mefhumlarının Tebeddülü, Mehmet Refik Fenmen'in (1882-1951) Einstein'ın Görelilik Teorisini tanıtmak için kaleme aldığı bir eserdir. Mühendis Mektebi ve Darülfünun fizik hocalarından, Mühendis Mektebi müdürlerinden elektrik mühendisi Mehmet Refik'in bu eserinin ilk baskısı 1922'de, ikinci baskısı 1924 yılında yapılmıştır. İki baskı arasında, gerek yöntem gerekse muhteva açısından belirgin farklııklar vardır. Latin harflerine aktardığımız bu ilk baskıda "medhal" başlığı altında bir giriş yazısı ve "fasıl" başlıklı 13 bölüm yer almaktadır. Herkesin anlayacağı bir şekilde kaleme alınan eser, bazı kusur ve noksanlıklarına rağmen Einstein'ın teorisi hakkında bildiğimiz kadarıyla Türkçe yazılmış ilk müstakil eser olması bakımından önemlidir. Eserin ilk altı bölümü özel görelilik, geri kalan yedi bölümü ise genel görelilik teorisi ile ilgilidir. Bu çalışmada Mehmet Refik'in Aynştayn Nazariyyesi adlı kitabı, ilk defa Latin harflerine harflere aktarılarak sunulmuştur. Yazarın üslubuna riayet etmek için Osmanlıca terimlerde sadeleştirme yapılmamış; çalışmanın sonunda okuyucuya kolaylık sağlaması için seçme bir sözlüğe yer verilmiştir.

Anahtar sözcükler: Einstein Nazariyyesi, Einstein'ın Görelilik Teorisi, Mehmet Refik Fenmen, Albert Einstein, Osmanlı Türkçesi, Bilim Tarihi

\section{ABSTRACT}

Aynştayn Nazariyyesi: Mekân, Zaman ve Kütle Mefhumlarının Tebeddülü is a book written in Turkish by Mehmet Refik Fenmen (1882-1951) to introduce Einstein's theory of relativity. It's first and second editions are dated 1922 and 1924. The first and the second editions are different in terms of method and content. The first edition includes an introduction and 13 chapters: Six chapters on special relativity, and seven on general relativity. Despite having some shortcomings, the book is written in plain Turkish. As far as we know it is the first Turkish book written about Einstein's theory. The text presented here 
is a first attempt to render the text in the Latin alphabet. Terms in Ottoman Turkish are not converted to modern Turkish in order to comply with the author's style. Instead, a glossary is given at the end of the text to facilitate the comprehension of the text by the general reader.

Keywords: Einstein's theory of relativity, Mehmet Refik, Albert Einstein, Ottoman Turkish, History of Science 


\section{Giriş}

On sekizinci yüzyıldan itibaren Osmanlı'nın özellikle askerî açıdan yaşadığı sorunlar, beraberinde bir çözüm yolu olarak modernleşme politikalarının ivme kazanmasına yol açmıştır. Başta eğitim-öğretim olmak üzere hemen her alanda görülen modernleşme çabalarının özellikle açılan mühendishaneler marifetiyle yürütüldüğü görülmektedir. Gerek yabancı öğretmenler gerekse Batı'da tahsil görüp geri dönen isimler sayesinde Osmanlı, modern bilim ile tanışma imkânını bulmuştur. Bu yüzyılda başlayan bilim metinlerini Türkçeye kazandırma çabaları on dokuzuncu yüzyılda da devam etmiş ve bu sayede müfredatın ana ekseninin Batılı bir çizgide oluşmasının zemini hazırlanmıştır. Modern fizik çalışmalarının Osmanlı'ya girişini bu çizgide değerlendirmek yanıltıcı olmayacaktır. Yahya Naci Efendi'nin on dokuzuncu yüzyılın hemen başında kaleme aldığı Risale-i Hikmet-i Tabiiyye'si (1809), Başhoca İshak Efendi'nin Mecmua-i Ulûm-ı Riyaziyye'si (1830-1834) ve Ali Sedad Bey’in termodinamik hakkında yazılmış bilinen ilk Türkçe eser olma özelliğini taşıyan Kavâid-i Tahavvülât fi Harekâti'z-Zerrât (1882) isimli eseri, Osmanlı yazarlarının fen bilimleri konusunda yaptıkları çeviri-derlemelere yalnızca birkaç örnektir. ${ }^{1}$

Osmanlı, Batı'nın modern bilim literatürünü çevirmekle meşgulken Albert Einstein, önce Özel Görelilik'i (1905) ardından Genel Görelilik'i (1907-1916) yayımlar. Bu açıdan Mehmet Refik'in Einstein hakkındaki bu mütalaası, Türk Bilim Tarihi açısından son derece kıymetlidir. İçerdiği bilgilerin niteliği hangi seviyede olursa olsun, bu teşebbüsün üstelik Millî Mücadele'nin devam ettiği bir savaş ortamında neticelenmesi her türlü takdirin üstündedir.

\section{Mehmet Refik'in Kısa Biyografisi}

Mehmet Refik Fenmen, 1882 y1lında, Preveze'de doğmuştur. İlköğrenimini İstanbul'daki Numûne-i Terakki Mektebinde, orta ve lise öğrenimini ise Saint Benoît Fransız Lisesinde tamamlamıştır. Bir süre Lozan Üniversitesi Matematik-Fizik Bölümüne devam etmiş; ardından Liège Üniversitesinden elektrik mühendisi olarak mezun olmuştur. 1908 y1lında Mekteb-i Sultanîde matematik öğretmenliği yapmış, daha sonra Ticaret ve Nafia Nezaretinde mühendisliğe tayin edilmiştir. Osmanlı Mühendis ve Mimarlar Cemiyetinin (OMMC) kurucuları arasında yer alan Mehmet Refik, derneğin ilk idare meclisinde kütüphaneden sorumlu üye olarak görev yapmıştır. 1910 yılında Mühendis Mektebinde Umûmî Fizik ve Elektrik dersleri vermiş; aynı yıl okulun müdürlüğüne getirilmiştir. 1910 yılında Avrupa’ya gönderilmiş; Almanya, Belçika, İsviçre ve diğer bazı ülkelerde yaptığı incelemeleri Osmanlı Mühendis ve Mimar Cemiyeti Mecmuası'nda yayımlamıştır. ${ }^{2}$

1 Ebru Ademoğlu, "Yahya Naci Efendi ve Fırlatılan Cisimlerin Hareketiyle İlgili Eseri 'Risale-i Hikmet-i Tabiiyye," Osmanlı Bilimi Araştırmaları 4 (2002): 25-56; Ekmeleddin İhsanoğlu, Başhoca İshak Efendi: Türkiye'de Modern Bilimin Öncüsü (Ankara: Kültür Bakanlığı, 1989); Levent Çankaya, "Ali Sedad'ın Kavâid-i Tahavvülât fî Harekâti'z- Zerrât Adlı Eseri, İçeriği ve Termodinamik ile İlgili Bölümlerinin Genel Bir Değerlendirmesi," Dört Öge say1 8 (2015): 75-87.

2 Meltem Kocaman, "Einstein'ın Görelilik Kuramı'nın Türkiye'ye Girişi” (Yüksek Lisans tezi, İstanbul Üniversitesi, 2002), 23. 
1919-1926 yılları arasında Darülfünûn'da Umumî Fizik dersleri veren Mehmet Refik, 1920'de Maarif Nezareti Yüksek Mektepler Genel Müdürlüğü ve 1921'de bu göreve ilaveten Meclis-i Kebir Maarif Azalığı yapmıştır. 1925-26 yılları arasında popüler bilim dergisi Fen Âlemi'ni çıkarmıştır. 1926'da Zonguldak Maden Yüksek Mühendis Mektebi Müdürlüğüne tayin edilmiştir. Bu görevinin yanı sıra 1928'de Ereğli Kömür İşletmeleri Genel Müdürlüğü yapmıştır. 1932'de İstanbul Mıntıkası Sanayi Müdürlüğü; 1934'te İktisat Vekâletine bağlı Elektrifikasyon Bürosu Azalığı; 1935-1943 yılları arasında Ankara Belediyesi Otobüs İşleri Direktörlüğü, 1943-1946 yılları arasında Kocaeli Milletvekilliği ve 1946 yılından itibaren çeşitli okullarda matematik öğretmenliği ve Etibank İdare Meclisi Azalığında bulunmuştur. Mehmet Refik, 4 Mart 1951 günü Ankara'da vefat etmiştir. ${ }^{3}$
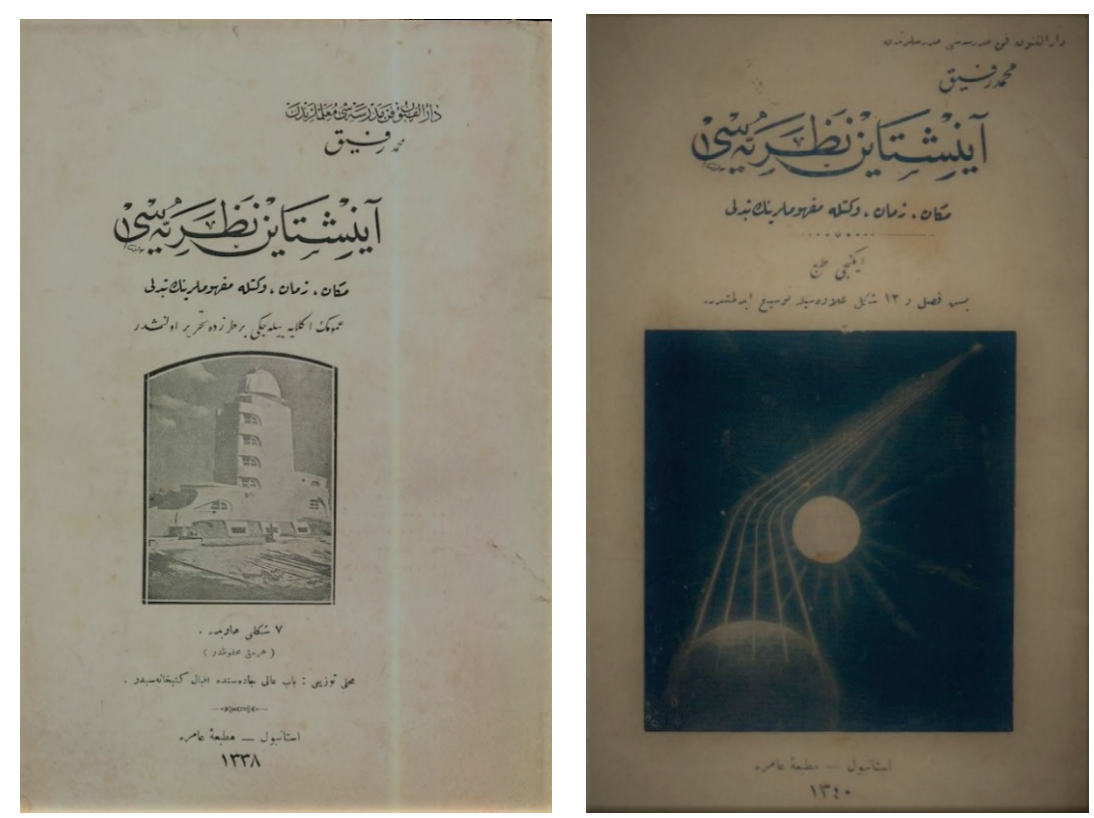

Mehmet Refik, Aynştayn Nazariyyesi. Solda 1. baskı 1338 (1922); Sağda 2. bask1 (1340/1924)

3 Kocaman, "Einstein'ın Görelilik Kuramı'nın," 24; Meltem Akbaş, "Elektrik Mühendisi Mehmet Refik Fenmen: Osmanlı'dan Cumhuriyet'e Yenilikçi ve Yorulmaz Bir Aydın," Osmanlı Bilimi Araştırmaları 9, 1-2 (2007-2008), 101-118. 


\section{Aynştayn Nazariyyesi: Mekân, Zaman ve Kütle Mefhumlarının Tebeddülü}

Mehmet Refik, çok sayıda eser vermiş üretken bir yazardır. ${ }^{4}$ Onun Aynştayn Nazariyyesi: Mekân, Zaman ve Kütle Mefhumlarının Tebeddülü isimli eseri de bildiğimiz kadarıyla Görelilik Teorisi hakkında Türkçe yayımlanan ilk Türkçe çalışma olması bakımından önemlidir. Eserin birinci baskısı 1922 yılında, ikinci baskısı 1924'de yapılmıştır.

Eserin iç kapak sayfasında "Dârü'l-fünûn Fen Medresesi Muallimlerinden Mehmet Refik, Aynştayn Nazariyyesi (Mekân, Zaman ve Kütle Mefhumlarının Tebeddülü), umûmun anlayabileceği bir tarzda tahrîr olunmuştur. 7 şekli hâvîdir. (Her hakkı mahfûzdur.) Mahall-i Tevzîi: Bâbıâli Caddesi’nde İkbâl Kütüphanesi'dir. İstanbul-Matbaa-i Âmire 1338 / 1922" ifadeleri yer almaktadır. Yeni harflere aktardığımız bu ilk baskıda "Medhal" başlığı altında bir giriş yazısı ve "Fasıll" başlı̆̆ı taşıyan 13 bölüm yer almaktadır. Eserin "Fihrist" sayfasında gösterilen bu bölümler aşağıdaki başlıkları taşımaktadır: 1. Fizo Tecrübesi [Fizeau Deneyi]; 2. Mikelson Tecrübesi [Michelson Deneyi]; 3. İzâfiyyet Kaide-i Esâsîsi [Görelilik İlkesi]; 4. Mekân ve Zamanın İzâfiyyeti [Mekân ve Zamanın Göreliliği]; 5. Kütle Mefhumu [Kütle Kavramı]; 6. Madde ve Kudret [Madde ve Enerji]; 7. Yeni Câzibe Kanunu [Yeni Çekim Yasas1]; 8. Ziyânın Vezniyyeti [Işs̆ğın Ağırlığı]; 9. Utârid'in Kapalı Bir Güzergâh Resmetmesi [Merkür'ün Kapalı Bir Yörünge Çizmesi]; 10. Ziyâ-i Şems Tayfındaki Çizgilerin Kırmızıya Doğru Tebdil-i Mekân Etmesi [Güneş Işığının Tayfındaki Çizgilerin Kırmızıya Doğru Yer Değiştirmesi]; 11. Yeni Mekân-Zaman Mefhûmu [Yeni Mekân-Zaman Kavramı]; 12. Kâinatın Mütenâhi fakat Hudutsuz Olması [Evrenin Sonlu fakat Sınırsız Olması]; 13. Aynştayn Nazariyyesinin Hayat-1 Ameliyyeye Tesiri [Einstein Teorisinin Gündelik Hayata Etkisi].

Eserin ikinci baskısında ise bu bölümlere ilaveten Lorentz'in İzahı, İzâfiyyet-i Mahduda, İzâfiyyet-i Mahduda Mebdei, Aynştayn’ın İzahı - İzâfiyyet-i Mahdudanın Tecrübevî Te'kidleri, İzâfiyyet-i Umûmiyye, Malumat-1 İbtidâiyye, Hareketin İzahı, Tedkik-i İtirazât ve Tashih-i Hatâyât adlı bölümlere yer verilmiştir. ${ }^{5}$

Aynştayn Nazariyesi’nin 1924 yılında yayımlanan ikinci baskısında bölüm sayısı 13 'ten 18 'e, sayfa sayısı ise 40'tan 72'ye yükselmiştir. Okuyucuların birinci baskıyı kısa bulduklarını söyleyen yazar, hem eserin bilimsel seviyesini yükseltmek için hem de eserin hacmini genişletmek maksadıyla ikinci baskıya beş bölüm daha ilave ettiğini belirtir. Fakat buna rağmen Mehmet Refik, ikinci baskıda sık sık çelişkiye düşmüş ve ilk yayının bilimsel

4 Meltem Akbaş, “Einstein'ın Görelilik Teorisini Türkiye’ye Tanıtanlar (I): Mehmet Refik Fenmen ve Kerim Erim," Osmanlı Bilimi Araştırmalarl 4, 2 (2003): 52-56.

5 Eserin eleştirel değerlendirmesi için bkz. Kocaman, “Einstein’ın Görelilik Kuramı’nın,” 33-41. 
seviyesini aşamamıştır. ${ }^{6}$ Bu bakımdan çalışmamız, eserin birinci baskısıyla sınırlı tutulmuştur.

\section{Metin}

[1] Dârü'l-fünûn Fen Medresesi muallimlerinden Mehmed Refîk, Aynştayn Nazariyyesi

(Mekân-Zaman ve Kütle Mefhûmlarının Tebeddülü). Umûmun anlayabileceği bir tarzda tahrîr olunmuştur. 7 şekli hâvîdir.(Her hakkı mahfûzdur.) Mahall-i Tevzî‘i: Bâbıâli Caddesi'nde İkbâl Kütüphânesi'dir. İstanbul - Matbaa-i Âmire 1338 / 1922.

\section{[2] Fihrist}

Sahife

Medhal

Birinci fasıl - Fizo Tecrübesi

İkinci fasıl - Mikelson Tecrübesi

Üçüncü fasıl - İzâfiyet Kaide-i Esâsîsi

Dördüncü fasıl - Mekân ve Zamanın İzâfiyyeti

Beşinci fasıl - Kütle Mefhûmu

Altıncı fasıl - Madde ve Kudret

Yedinci fasıl - Yeni Câzibe Kanunu

Sekizinci fasıl - Ziyânın Vezniyyeti

Dokuzuncu fasıl - Utârid'in Kapalı Bir Güzergah Resmetmesi

Onuncu fasıl - Ziyâ-i Şems Tayfındaki Çizgilerin Kırmızıya Doğru Tebdil-i Mekân Etmesi

On birinci fasıl - Yeni Mekân-Zaman Mefhûmu

On ikinci fasıl - Kâinatın Mütenâhî fakat Hudutsuz Olması

On üçüncü fasıl - Aynştayn Nazariyyesi’nin Hayât-1 Ameliyyeye Tesiri

\section{[3] Medhal}

Efkâr-1 ammede yerleşmiş bir kanaâte göre şu içinde yaşadığımız kâinat, basit birtakım hâdisâtın makarrı olduğu halde, fikr-i beşerin nazariyyâta pek ziyâde münhemik olması

6 Akbaş, “Einstein’ın Görelilik Teorisini Türkiye’ye,” 46-48. 
hasebiyle, ulemânın hakîkate pek de tevâfuk etmeyen muğlak birtakım nazariyyât ve tahayyülâta kapıldıkları zannolunuyor. Hâlbuki bilhassa şu son zamanlarda keşfolunan hâdisât-1 cedîde, nazar-1 im‘âna alınırsa bu mütâlaanın vârid olmadığı ve insanların ancak hâdisât-1 tabîiyyenin teşvikât-1 rûz-merresiyledir ki ilmin kademe kademe teâlî ve tekâmülünü vücûda getirmekte oldukları teslîm olunur.

Âlem-i tabiat öyle bir harika-i hilkattir ki ilmimizin en derin esâsâtından istihrâc eylediğimiz netâyic bile belki vüs'at ve azametini tamamen ihâta etmekliğimize kâfil bulunamamaktadır. El-yevm mekteplerimizde tedrîs olunan ilmin müessisi olan Newton bile hâdisât-1 tabîiyyenin vüs'ati karşısında mebhût ve mütehayyir kalarak demiştir ki "Ben sâhil-i bahrde oynayan ve ara sıra daha güzel bir çakıl taşı bularak eğlenen bir çocuk gibiyim. Önümdeki umman-1 hakîkat ise bana daima muhtefî kalıyor.”

İşte sâhil-i bahrde oynarken bulduğu şeylerle tezyîd-i merak eden bir çocuk gibi âlimler dahi nazar-1 dikkatlerini celb eden hâdisât-1 tabîiyyeyi izaha teşebbüs ederlerken şu ummân-1 meçhulât içinde yeni yeni ufuklar açabilmek için esâsât-1 ilmiyyeyi daha metîn yani hakîkate daha mukârin temeller üzerine bina eylemeğe gayret etmektedirler.

Ulema, taharrî-i hakîkat ma'rekesinde istihsâl eyledikleri malumâtın mukârin-i hakîkat olup olmadığının tahkîkini en ibtidâî ve en mühim bir vazife addedip bunun için de tecrübeye müracaat ederler. Fi'l-vâki tecrübe, hakîkatin yegâne menbaını teşkîl eylediğinde bugün kimsenin şüphesi kalmamıştır.

[4] Bir nazariyye metîn bir surette tesis etmiş olmak için nazariyye-i mezkûreden istihrâc olunan bi'l-umûm netâyicin bi’t-tecrübe te'kîd eylemesi şarttır. Malumdur ki mühendisler dahi birtakım hesâbât-1 tavîleye müsteniden inşâ ettirdikleri bir köprünün şâyân-1 kabul olup olmadığını tahkîk için tecrübeye müracaat ederler: Bir köprü her gün üzerinden mürûr edecek olan yüklerin en büyügünnden birkaç misli fazla bir yükle tahmîl edildiği halde buna tahammül ederse köprünün projeye tevâfuk eylediği anlaşılarak mürûr u ubûra küşâd edilir.

İşte bugün izah etmek istediğim Aynştayn nazariyye-i cedîdesi dahi tecârüb-i adîde ile te'kîd ve vukûunu evvelden ihbâr eylediği hâdisâtın cümlesi bi’t-tecrübe isbât edildiği için hakîkate muvâfik bulunduğunu kabul etmek mecburiyetindeyiz.

Evvela Aynştayn kimdir? Ve kâinatı bize daha iyi tanıttırmağa muvaffak olan nazariyyesini nasıl tesis etmiştir? Newton Nazariyyesi'nin mukârin-i hakîkat olmadığını meydan-1 sübûta vaz' eden hâdiseler neler olmuştur? Bu hâdisâtı izâh için Aynştayn mekân, zaman ve madde hakkındaki efkâr-1 ibtidâiyyemizi nasıl tadîl etmiştir? "İzâfiyyet" namıyla yâd olunan bu nazariyye-i cedîdeden istihrâc olunan netâyic nelerden ibarettir? Hayat-1 ameliyyemize bunların derece-i tesiri nedir? İşte eserimizin mevzuunu bu meseleler teşkîl edecektir. 


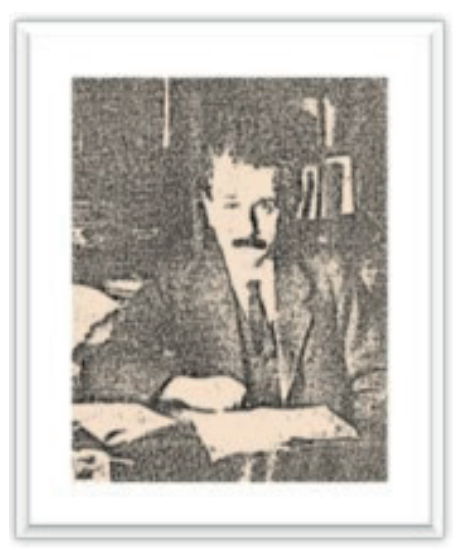

Şekil 1.

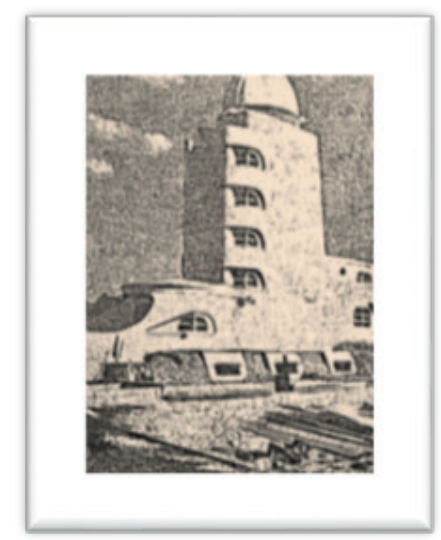

Şekil 2.

Musevî bir Alman ailesine mensup olan Aynştayn, elyevm 43 yaşındadır. Tahsîl-i tâlisini kısmen Almanya'da ve kısmen de İsviçre'de ikmâl ettikten sonra Zürih Dârü'l-fünûnu'nda ulûm-1 riyâziyye ve hikemiyyeyi tahsîl eylemiştir. Dârü'l-fünûn'dan neş'et ettikten sonra Bern şehrinde ihtirâ‘ beratı mesâiliyle [5] mütevaggıl bir yazıhaneye devam ve aynı zamanda riyâziyyat doktorluğu imtihanını hazırlayarak 1905 senesinde bu imtihanı muvaffakiyetle geçirmiştir. Dört sene sonra Zürih Dârü'lfünûnu muallimliğine ve buradan Prag Dârü'l-fünûnu muallimliğine tayin edilmiş ve yine Zürih Dârü'l-fünûnuna muallim sifatıyla avdet etmiştir. Nihayet 1914 senesinde yani Harb-i Umûmi ilânı senesi Almanya'ya davet olunarak uhdesine Berlin Dârü'l-fünûnu Nazarî Fizik Muallimliği ve bu Dârü'l-fünûna mülhak Fizik Dârü'l-mesâisi Müdüriyeti ve Prusya Fen Akademisi azalığı tefvîz edilmiş ve el-yevm vezâif-i âliye ile meşgul bulunmaktadır.

Bugün izah etmek istediğim ve namının aktâr-1 cihanda yâd edilmesine sebep veren İzâfiyyet Nazariyyesi'ni Aynştayn, henüz 26 yaşında iken 1905 senesinde yani bundan 17 sene mukaddem tesîs eylemiştir. Velûd bir sa'y-i mütemâdî ile nazariyyesini her sene bir derece daha tevsi'e ve hâdisât-1 mütenevviaya teşmîle muvaffak olan bu âlim, cemiyet-i beşeriyyenin bugüne kadar yetiştirdiği dâhilerin en büyüklerinden biri addedilmeğe layıktır.

[6] Aynştayn, ilmimizin esâsâtını tagyîr etmiş ve şu içinde yaşadığımız kâinatın mahiyet-i hakikiyyesini bize göstermek üzere ilmini, esâsât-1 metîne üzerine kurmağa muvaffak olmuştur. Nazariyyesini tevsi‘ ve tecrübe ile tahkîk etmek üzere bu defa Berlin civarında Potsdam'da muhteşem bir rasathâne inşâ olunmuştur.

Aynştayn'ın malumât-1 fenniyemizi ne derece tebdîl eylediği basit misaller ile izah edilebilir: Bir sokağın tûlünü hatasız olarak ölçen iki mühendisten biri diğerinden daha seri bir süratte ölçerse her ikisinin de bulacağı neticeyi müsâvi addediyorduk. Hâlbuki İzâfiyyet Nazariyyesi mûcibince sokağın tûlünü daha süratle ölçenin istihsâl eyleyeceği netice, daha batî bir sûrette ölçenin bulacağı neticeden daima efzûn olur. Kezâ demiryolu civarında duran bir şahsa göre süratle mürûr eden bir tren tûlünün, hâl-i tevakkuftaki tûlüne müsâvi olmadığını 
Aynştayn iddia ediyor. Hâlbuki Newton'dan bize intikâl eden malumât-1 fenniyyeye göre tren ister hâl-i tevakkufta ister harekette bulunsun tûlü birdir.

Hakîkatın mi‘yârı olan tecrübe, Aynştayn'a hak veriyor. Demek ki malûmât-1 umûmiyyemizin erkân-1 aslîyye ve ibtidâiyyesini teşkîl eden mekân ve zaman mefhûmlarımız bile doğru değilmiş. Fikr-i beşerin bu derece yanılmış olacağını kim tasavvur edebilirdi!

Aynştayn bu netâyic-i hârikulâdeye nasıl vâsıl oldu? Takip eylediği tarîk şundan ibarettir: Eski malûmâtımızla izahına muktedir olamadığımız iki tecrübe-i hikemiyye nazar-ı dikkati celb etmiştir: [7] Bu tecrübelerden biri Fransız hikmet-şinâsânından Fizo'nun [Fizeau] ve diğeri de Mikelson [Michelson] isminde Amerikalı bir âlimin icrâ eylediği bir ziyâ tecrübesidir. Bu tecrübelerin Newton'dan bize intikal etmiş olan ilmimizle izâhı mümkün olamadığını müşâhede eden Aynştayn, Dekart'ın [Descartes] meşhur bir sözünü hatırlamış olsa gerektir: Dekart [Descartes] diyor ki "Hakîkate vâsıl olmak için insan, ömründe hiç olmazsa bir defa her şeyden mümkün mertebe şüphe etmelidir."

İşte Newton Nazariyyesi'nin sıhhatinden şüphe eden Aynştayn, bizi hakîkate daha ziyade yaklaştırmış oluyor. Aynştayn'ı İzâfiyyet Nazariyyesi’ne sevk eden Fizo [Fizeau] ve Mikelson [Michelson] tecrübeleri hakkında bir nebze izâhât arz etmek isterim.

\section{[8] Birinci Fasıl - Fizo [Fizeau] Tecrübesi}

Eski zaman ve mekân malumâtımızla, yani Newton Nazariyyesi’yle kâbil-i izah olmayan hâdisâttan biri de ziyânın müteharrik bir madde derûnunda mesela bir su veya hava cereyanı dâhilindeki sürat-i intişârı hâdisesidir. Bir hav[u]za attığımız taşın husûle getirdiği dâirevî dalgalar nasıl her tarafa intişâr ederse bir menba'-1 ziyâdan dahi etrafa birtakım dalgaların yayıldığ malûmdur. Bu temevvücât-1 miyâhiyye havuzda su vasıtasıyla, temevvücât-1 ziyâiyye ise fezâda esîr dediğimiz gerek madde derûnunda ve gerek boşluklarda mevcudâtı farz olunan bir madde-i mahsûsa iânesiyle, saniyede 300.000 kilometre süratle intişâr eylediği umûmen kabul edilmiştir.

Bir madde, mesela bir hava kütlesi hareket ederken acaba ihtivâ eylediği esîri de birlikte sürükler mi yoksa esîr bu harekete iştirâk etmeyerek tamamen âtıl mı kalır? Esîr, hava ile birlikte hareket ediyorsa hava cereyanını hâvi bir borunun içinden geçirilen bir şu'â-ı ziyâînin sürati, bi’t-tabi' hava cereyanının süratine tâbi olacak. Her ikisi de aynı ciheti hâiz olursa şu'â-1 ziyâînin sürati, râkid bir hava kütlesi dâhilindeki süratiyle cereyan-1 hava süratinin mecmû'una müsâvi olmalıdır. Nitekim ki hareket halinde bulunan bir trenin içinde koşan bir adamın karada bulunan bir kimseye göre sürati, trenin süratiyle bu adamın, trene nazaran süratinin mecmû'una müsâvi olduğu Newton Nazariyyesi îcâbındandır.

İşte Fizo [Fizeau] ismindeki Fransız hikmet-şinâs1, pek merak-âver olan bu tecrübeyi bi'l-icrâ, hâl-i harekette bulunan hava ile gazâtta sürat-i ziyânın râkid havadaki kıymetini 
muhafaza eylediğini göstermiştir. Demek oluyor ki 1slak bir süngerin, hâvî olduğu suyu birlikte nakl eylemesine muhalif olarak, maddenin hareketi, içindeki esîrin de hareketini mûcib olmuyor. İşte Fizo [Fizeau] tecrübesinden istihrâc olunan netice budur.

\section{[9] İkinci Fasıl - Mikelson [Michelson] Tecrübesi}

Mütâlaât-1 sâlife, esîrin sükûnet-i mutlaka içinde bulunduğunu gösteriyor. Şu halde arz, Güneş etrafında sâniyede 30 kilometre süratle hareket eylerken havadaki esîr, bu harekete iştirâk etmeyeceğinden, sath-1 arz üzerinde bulunan bir şahıs tarafından muhtelif istikametlere tevcîh olunacak şuâât-1 ziyâiyye, şahs-1 mezkûre göre muhtelif süratleri hâiz olacak. Eğer râsıd-1 mezkûr, şuâ-1 ziyâîyi arzın hareketi cihetine tevcîh ederse kendisi de arz ile birlikte bu cihete doğru ilerlediğinden şu'â-i ziyâînin kendine göre sürati, saniyede 300.000 kilometreden, sürat-i arz olan saniyede 30 kilometre noksan olmak îcâb eder. Bilakis bu râsıd şuâ-i ziyâyı, arzın cihet-i hareketinin aksi tarafına tevcîh ederse bu iki sürat birbirine inzimâm ederek sürat-i ziyânın saniyede 300.000 kilometreden 30 kilometre fazla bir kıymette bulunması lazım gelir. İşte bu neticeyi tahkîk için Mikelson [Michelson] tecrübeye müracaat etmiştir.

Mikelson'un [Michelson] bu tecrübesini Boğaziçi'nde tasavvur edebileceğiniz bir kayık yarışı ile izah edeceğim: Müsâvi kuvvette ve râkid suda bir kayığa mesela dakikada elli metre mesafe katettiren iki kayıkçı arasında Boğaziçi’nde, akıntının mesela dakikada otuz metre sürati hâiz olduğu Rumeli Hisarı'nda bir yarış tertip edelim: Yüz metrelik muayyen bir mesafeyi ister Baltalimanı tarafına doğru gidip gelmek, yani bidâyette akıntıya karşı çıkıp müteâkiben akıntı ile avdet etmek ve ister iki karşı sahil arasındaki müsâvi bir mesafeyi akıntıya amûden gidip gelmek suretlerinden birinin intihâbında kayıkçıları [10] muhtâr bırakalım. Farz edelim ki birisi tarîk-i evveli ve diğeri de tarîk-i sânîyi tercih etmiş olsun.

Tarîk-i evveli intihâb eden kayıkçı, akıntıya karşı çıkarken sürati dakikada 50-30 yani 20 metre olduğundan yüz metroluk [metrelik] mesafenin nihayetine 5 dakikada vâsıl olur. Avdette ise sürati $50+30$ yani 80 metre olacağından $1 \frac{1}{4}$ dakikada avdet eder. Bu şıkkı kabul eden cem‘an $6 \frac{1}{4}$ dakika sarf etmiş olur.

İkinci şıkkı tercih eden kayıkçı ise akıntıya amûden gidip gelmek mecburiyetinde bulunacağından akıntıya rağmen karşıya vâsıl olmak yani Rumeli Hisarı'ndan Anadolu Hisarı'na geçebilmek için kayığına Kanlıca'ya doğru bir istikâmet vermesi îcâb eder. Bu istikameti öyle bir sûretle intihâb edecek ki kendisi, râkid suda, Rumeli Hisarı - Kanlıca mesafesini katettiği müddet zarfında, Kanlıca tarafında nişan aldığı nokta, akıntı süratiyle Anadolu Hisarı'na vâsıl olmuş olsun. Demek oluyor ki bu müselles-i kâimü'l-zâviyenin veter-i kâimesinin, Anadolu Hisar1-Kanlıca d1l1'-1 kâimine nisbeti $\frac{50}{30}$ nisbetine müsâvi olmak 


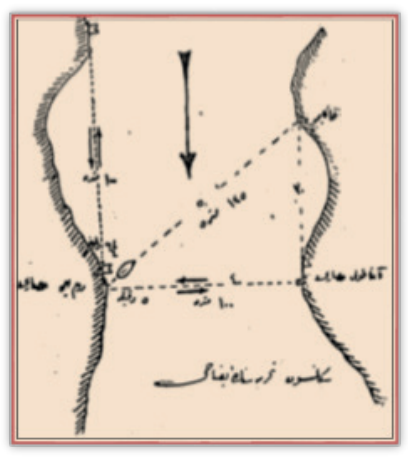

Şekil 3.

lazım geldiğinden Hisar'dan Hisar'a olan mesafe bunlara nazaran yalnız 40 metre nisbetinde olmak lazım gelir. Hâlbuki bu mesafe 100 metreye müsâvi farz edilmiş olduğundan Rumeli Hisarı - Kanlıca istikameti 125 metre olur. Ve bu mesafeyi kayıkçı 2,5 dakikada kat eder. Avdet için de aynı zaman sarf edileceğinden cem'an karşıdan karşıya gidip gelme zamanı 5 dakikadan ibaret olur. Hâlbuki akıntıya karşı gidip müteâkiben avdet zamanı 6,25 dakika idi.

[11] İşte bildiğimiz mihânik kavâidi bizi bu neticeye sevk ettiği halde Mikelson [Michelson] tecrübesinde, şu tasavvur eylediğimiz kayık yarışında olduğu gibi şuâ-i ziyâînin de arzın hareketi cihetine gidip gelmesi için sarf edeceği zamanın bu harekete amûdî istikamette ve aynı mesafe üzerinde gidip gelme müddetine müsâvi olmasına intizâr olunurken bu intizârın hilâfında olarak ziyânın her iki tarîki ayn[1] zamanda kat eylediği tebeyyün ediyor. Demek oluyor ki ziyânın sürat-i intişârı, râsıdın cihet-i hareketine tâbi‘ değildir.

\section{[12] Üçüncü Fasıl - İzâfiyet Kâide-i Esâsîsi}

Evvelce zannolunuyordu ki sath-1 arzda bulunan bir şahsa nazaran ziyâ, saniyede 300.000 kilometre sürat ile intişâr eylediği halde, mesela bir tayyare içinde sürat-i azîme ile uzaklaşan bir kimseye göre, ziyâ başka bir sürati hâiz. Mesela öyle bir tayyare tasavvur ediniz ki saniyede 100.000 kilometre sürat-i hârikulâdesiyle bizim bulunduğumuz mevkiden uzaklaşsın. Bu tayyare râsıd ile birlikte tebâüd ederken kendisine bir işaret-i ziyâiyye irsâl edersek mademki ziya bize nazaran saniyede 300.000 kilometre sürat ile uzaklaşıyor; her saniyede bu işaretimizin tayyareye 300.000 - 100.000 yani 200.000 kilometre yaklaşması yani tayyareciye nazaran ziyânın saniyede 200.000 kilometre sürat ile takarrüb etmesi îcâb edecek.

Mikelson [Michelson] tecrübesi, bu zannın bâtıl olduğunu yani bizden saniyede 300.000 kilometre sürat ile tebâüd eden bir işâret-i ziyâîyyenin tayyareciye göre de saniyede 300.000 kilometreye müsâvi olduğunu gösteriyor. İşte bu tecrübeye istinâden der ki Aynştayn "İzâfiyet, kâide-i esâsiyyesini tesîs ederek demiştir ki: Bir râsıda nazaran kavânin-i tabîiyye nasılsa buna göre müteharrik diğer bir râsıda nazaran da kavânin-i mezkûre aynen öyledir."

Ez-cümle telakkî eylediğimiz tayyareci, sath-1 arzdan gönderdiğimiz işâret-i ziyâiyyenin kendisine nazaran süratini tayin için bir tecrübe icrâsıyla mesela işâret-i ziyâiyyenin râkib bulunduğu tayyarenin iki noktasından an-1 mürûrunu bir sürat ile takdîr edecek olursa şuâ-i 
ziyâinin kendisine nazaran da saniyede 300.000 kilometre sürat ile intişâr ettiğini bi’t-tecrübe müşâhede eder.

\section{[13] Dördüncü Fasıl - Mekân ve Zamanın İzâfiyeti}

Bâlâda izah olunan netice, şimdiye kadar fikr-i beşerin kabul eylediği mekân ve zaman mefhumlarıyla gayr-i kâbil-i izâhtır. İşte bunun içindir ki İzâfiyet Nazariyyesi cümlemize biraz garip görünüyor ve eski mefhumlarla yoğrulmuş olan dimağlarımız bunu kolaylıkla kabul etmek istemiyor.

Kâinat, bizim tarz-1 tefekkürümüze göre tebdil-i mâhiyet edecek değil ya! Hiç şüphe yok ki bilakis biz, ilmimizi hâdisât-1 tabîiyyeye tevfîke mecburuz.

Malum olduğu üzere sürat, bir mesafenin bir zamana nisbetine müsâvi olduğundan ziyâ süratinin bâlâda telakkî olunan tayyareye göre zannımız vechile saniyede 200.000 kilometre olmayıp da 300.000 kilometreye müsâvi olması tayyâredeki râsıda göre bir metre tûlün bize nazaran bir metreye müsâvi olmadığını ve tayyareciye göre bir saniyelik müddetin bize nazaran bir saniyeye müsâvi olmadığını ispat eder.

İşte bu mütâlaaya istinaden Aynştayn, tayyareciye göre bir metreye müsâvi bir tûlün arzdaki şahsa göre bir metreden dûn ve tayyareciye göre bir saniyelik zamanın arzdaki şahsa nazaran bir saniyeden efzûn olduğunu kabul etmek zarûreti karşısında bulunduğumuzu beyan etmiştir. Daha umûmî bir ifâde ile diyeceğiz ki: "Birbirine nazaran harekette bulunan iki râsıd telakkî olunursa birinin hareketi istikametinde bulunan her tûl, diğerine nazaran kısalmış olacak ve her saniyelik zaman da uzamış bulunacak." [14] Yani tûl u zaman, telakkî olunan râsıda göre mütehavvil ve izâfî bir mahiyeti hâizdir. İşte tecrübenin bize bildirdiği hakîkat budur.

Tayyaredeki râsıdı, hareket-i istikametinde bulunan her tûlünün bize nazaran kısalmış olduğu ve saatinin daha yavaş işlediği hususunda ikna edemeyiz. Zira böyle bir iddiamız üzerine kendisi, tûlü malum olan tayyaresini bir metre ile bir kere daha ölçmeğe kıyam edecektir. Bu mesâha, kendisine tayyaresinin yine aynı tûlda bulunduğunu göstereceğinden iddiamızı kabul etmeyecek. Fakat hakîkat halde bize nazaran tayyarecinin metresi de tayyaresi gibi aynı nisbette kısalmış olacağından netice-i mesâhatta bir fark bulamayacağı derkârdır.

Bizim tayyare hakkındaki muhakememizi, tayyareci de aynen bize tatbik ederek elimizde hareket-i istikametine müvâzi tuttuğumuz metrenin kısalmış olduğunu ve saatimizin kendi saatinden daha yavaş işlediğini iddia edecektir. Zira tayyare bizden uzaklaşıyorsa biz de tayyareye nazaran aynı süratle uzaklaşıyoruz.

İşte şimdiye kadar kabul edildiğinin aksine olarak vâhid-i tûl ile vâhid-i zamanın, râsıdın hareketine göre başka başka kıymetleri hâiz olduğunu ispat eden İzâfiyet Nazariyyesi, en basit ve en esaslı mâlumâtımızı alt üst etmiş oluyor. 
Basit bir hesap ile ispat ediliyor ki saniyede 260.000 kilometre sürat ile hareket eden bir tayyarenin tûlü, arzdaki râsıda göre yarı yarıya tenâkus edecek ve tayyareciye göre bir müddet devam eden her hâdise, mesela yarım saat devam eden sigarası arzdaki râsıda göre iki misli yani bir saat devam edecek!

Tayyarenin sürati tedrîcen tezâyüd edip de sürati, ziyâ süratini ihrâz ederse arzdaki râsıda göre tayyarenin tûlü de tedrîcen sıfıra müncerr olacak. Tayyarecinin bir saniyelik müddeti ise bize göre nâmütenâhi uzamış olacak, yani zamanı âdeta tevakkuf seyr edecek. [15] Şâirin : "Ey çarh tevakkuf et, zaman ver / Ey saat-i sa'd, aman ver" diye ref" eylediği nida, husûlpezîr olmuş olacak. Fakat tayyareciye gelince kendisinde hiçbir tahavvül hissedemeyecek ve bize göre kımıldamak imkânsızlığında bulunduğunun farkına bile varamayacak! Hayretimize kendisi de hayret edecek!

\section{[16] Beşinci Fasıl - Kütle Mefhûmu}

Tecârib-i rûz-merre ile sâbittir ki bir arabayı iten bir şahsın birinci saniye nihayetinde ona ihrâz ettirdiği sürat, aynı zatın iki arabayı birden ittiği zaman bu arabaların ahz eylediği süratten daha büyüktür. İşte ecsâmın hâl-i sükûnetten hâl-i harekete gelmelerine îkâ'-i müşkilâta sâî bulunan bu hassaları, kütlelerinin adem-i müsâvâtıyla izah olunmaktadır. Bir cismin kütlesi ne kadar büyük olursa muayyen bir kuvvetin taht-1 tesirinde birinci saniye intihâsında ihrâz eylediği sürat de o kadar daha dûn olur.

El-yevm mekteplerimizde kütle-i ecsâmın sabit olduğunu yani süratle tahavvül eylemediğini tedrîs ediyoruz. Ve bunun neticesi olarak da bir kuvvetin taht-1 tesirinde hareket eden bir cismin, ikinci saniye nihayetinde ihrâz eylediği süratin, birinci saniye nihayetindeki kıymetinin iki misli ve üçüncü saniye nihayetinde de üç misli ve bu minval üzere süratinin ilâ-nihâye tezâyüd edeceğini talebemize öğretiyoruz.

İşte Newton Nazariyyesi'nde süratlerin bu sûretle nâmütenâhi tezâyüd edebilmesi kabul ediliyor. Hâlbuki İzâfiyet Nazariyyesi, bazı hâdisât-ı elektrikıyyede sürat-i azîmeyi hâiz, ecsâm-1 sagîre hareketinin tetebbu'u neticesinde bu sûretle tezâyüd eden süratlerin bir gayesi mevcut olduğunu ve bu gayenin de sürat-i ziyâ olan saniyede 300.000 kilometreden ibâret olduğunu ve dünyada hiçbir süratin, sürat-i ziyâyı tecavüz edemeyeceğini ispat etmiştir. Misal olarak saniyede 200.000 kilometre gibi bir sürat-i fevkalâde ile uçan bir tayyarede bulunan bir mitralyözün tayyareciye nazaran saniyede 200.000 kilometre süratini hâiz mermiler endâht eylediğini tasavvur edersek hepimizin bildiğimiz mihânik kavâidi [17] mûcibince bu mermilerin karada bulunan bir râsıda göre sürat-i mecmuası, saniyede $200.000+200.000$ yani saniyede 400.000 kilometreye müsâvi olması lazım gelir. Hâlbuki İzâfiyet Nazariyyesi mûcibince hakîkat halde mermilerin bize göre sürat-i mecmuasının saniyede 400.000 değil; fakat saniyede 277.000 kilometreden ibâret olacağı anlaşılıyor. 
Bu netice, mütâlaât-1 sâlifeye nazaran bizi katiyyen hayrete düşürecek mahiyette değildir. Zira tayyarenin hareket-i istikametinde bulunan ve tayyareciye göre bir metreye müsâvi her tûlün bize göre daha kısa olacağını bâlâda izah etmiştik. Bu kısalmış metre ile tayyarecinin kendine göre mesâha ettiği 200.000 kilometreyi biz, tûl-i aslîsini muhafaza eden metromuzla [metremizle] mesâha edince mermilerin sürati olarak saniyede ancak 77.000 kilometre buluruz ki bunda da mûcib-i istigrâb bir şey yoktur.

Demek oluyor ki demin sabit bir kuvvetin taht-1 tesirinde hareket eylediğini tasavvur ettiğimiz cismin sürati, her saniyeyi müteakip müsâvi miktarda tezâyüd edemeyecek. Çünkü bunun sürati hiçbir zaman sürat-i ziyâyı tecavüz edemeyeceğini tecrübe gösteriyor. Şu halde aynı kuvvet bir cismin süratini her saniyeyi müteakip daha az tezyîd edecek.

Hâlbuki bir cisim, sabit bir kuvvetin taht-1 tesirinde bulunduğu halde, süratinin gittikçe daha az tezâyüd etmesi kütlesinin süratiyle birlikte tezâyüd eylemekte olduğunu gösterir. Neticede kütle-i maddiyyenin sabit bir kemmiyyet olmayıp bir cismin sürati tezâyüd edince kütlesinin de tezâyüd eylediğini kabul etmek zarureti karşısında bulunuyoruz.

Dûn süratlerde farkına varamadığımız bu kütle tahavvülü, sürat-i azîmeyi hâiz ecsâmda nazar-1 dikkati câlibdir. Bilhassa röntgen şuââtını tevlîd eden ve saniyede 200.000 kilometreye kadar sürati hâiz bulunan elektrik zerrelerinin yani elektronların süratlerinin tezâyüdüyle kütlelerinin de Aynştayn tarafından hesap edildiği üzere, câlib-i nazar bir raddede arttığg bi’ttecrübe anlaşılmaktadır.

[18] Ez-cümle Aynştayn düsturlarıyla yapılan hisâbât neticesinde 1.000 gramlık bir kütleyi hâiz bulunan bir cismin sürati, saniyede 1.000 kilometreye bâliğ olursa kütlesi 2 santigram tezâyüd ediyor. Bir cismin sürati saniyede 260.000 kilometreyi bulunca kütlesi tezâuf etmektedir.

İşte şimdiye kadar en sağlam zanneylediğimiz kütle-i maddiyye hakkındaki malumâtımızın da İzâfiyyet Nazariyyesi'yle alt üst olduğu ve son tahlilde kütle-i ecsâmın da mekân ve zaman gibi izâfî bir kıymeti hâiz bulunduğu izâhât-1 sâlife ile tebeyyün ediyor.

\section{[19] Altıncı Fasıl - Madde ve Kudret}

On dokuzuncu asr-1 mîlâdîde husûle gelen terakkiyât-1 ilmiyye, hadisât-1 hikemiyye ile kimyeviyyenin ayrı ayrı nokta-i nazarlardan telakkisini mûcib olmuştur, şöyle ki: Hâdisât-1 hikemiyye, tahavvülât-1 kudret ${ }^{7}$ şeklinde ve hâdisât-1 kimyeviyye ise tahavvülât-1 madde-i hâdisât suretinde ve yekdiğerinden tamamen müteferrik birer şube-i ilmiyye olarak nazar-1 itibara alınmış ve "kudretin zâil olamayacağını ve ancak bir halden muâdil diğer bir hâle

7 Kudret ve tahavvülâtı hakkında daha mufassal malumat edinmek için (Fenn-i Elektrik ve Tatbikat-1 Sanaiyyesi) namındaki eserime müracaat edile. 
mürûr edeceğini" ifade eden tahaffuz-1 kudret kanununa mukabil "maddenin de kâbil-i izâle olmadığını ve ancak bir halden diğer bir hale ifrâğ edebileceğini” müeyyed olarak tahaffuz-1 madde kanununun câri bulunduğu umûmen kabul edilmişti. Hikmet-şinâsânın âlem-i kudreti, kimyagerlerin ise âlem-i maddiyyâtı tetebbu' eyledikleri telakkisi câri idi.

Gerçi asr-1 sâbık sonlarına doğru bir taraftan hâl-i harekette bulunan elektriklenmiş ecsâmın hâiz olduğu atâletin, süratlerine göre mütehavvil bulunduğu ve diğer taraftan da radyum gibi kendiliğinden neşr-i kudret etmek hassâsını hâiz yani faaliyet-i inşiâiyye hassasına mâlik bazı ecsâmın keşfedilmesi üzerine kudret ile madde arasında bir mukârenetin mevcudiyeti anlaşılmışsa da bu hususta ulemâ pek ileriye varamamışlardı.

Esasen neşr-i inşiâ eden bir cismin, cihet-i inşiâın aksine doğru gerilediği ve inşiâ-i mezkûru bel' veya aks eden ecsâmın da bir tazyîke maruz bulunduğu daha evvelleri malum olmuştu. "Tazyîk-i inşiâ" namıyla yâd olunan bu tesîr, aynıyla bir silahtan çıkan merminin silah-1 mezkûrda husûle getirdiği gerilemesine ve merminin isabet ettiği cismin de ilerlemesine müşâbihtir.

[20] İşte kudret ve madde hakkındaki malumât-1 sâbıkamızla kâbil-i telif olmayan bütün bu hâdisât, Aynştayn tarafından kütlenin bâlâda izâh edildiği üzere, sürat-i ecsâm ile mütehavvil bulunduğu nazar-1 itibara alınarak ve elektrik nazariyyâtına istinâden şümûllü bir surette izâh edilmiş ve birbirinden tamamen müteferrik ve müstakil olan tahaffuz-1 kudret ve tahaffuz-ı madde kanunlarının tevhidine muvaffakıyet hâsıl olmuştur.

Fi'l-vâki sürat-i azîme ile hareket eden bir cisim, sürati, dûçâr-1 tahavvül olmayarak bir miktar hararet bel' eder yahut cism-i mezkûr bir huzme-i ziyâiyye ile tenvîr veya bir hamûle-i elektrikıyye ile tahmîl edilirse süratinde bir gûnâ tahavvül husûle gelmeyen cism-i mezkûr kütlesinin tezâyüd ve bilakis eğer cism-i müteharrik neşr-i inşiâ ederse kütlesinin tenâkus edeceğini Aynştayn, nazariyât-1 elektrikıyyeye istinaden ispat etmiştir.

Demek oluyor ki hâl-i harekette bulunan ve hariçten bir miktar hararet bel' eden veya tenvîr edilen ve elektriklendirilen bir cismin kütlesiyle vezni hâl-i sükûnette bulunan soğuk, mazallem ve elektrikıyyetten muarrâ bir cismin kütlesiyle vezninden efzûn olacak.

İzâfiyyet Nazariyyesi'ne göre bir imtizâc-1 kimyevîde sabit kalan kemmiyyet yalnız birbirine tesir eden ecsâmın kütle-i mecmuası değil fakat bu imtizâc hâdisesinde intişâr eden veya bel' edilmiş olan hararet, ziyâ ve elektrikıyyet gibi kudretlerle kütle-i maddiyyeler mecmûudur ki lâyetagayyer ve sabit kalır. Bizim mesâha usullerimiz sıhhat-i kâfiye temin edemediği ve kütlenin miktar-1 tahavvülü pek cüzî olduğu cihetle, kanun-1 hakîkatin şimdiye kadar izhârına muvaffakiyet hâsıl olamamıştı. Fakat bu hâdiseler İzâfiyyet Nazariyyesi’yle tahlil edilince "kudret ile maddenin kâinatı teşkil eden unsur-1 ibtidâinin birer şeklinden başka bir şey olmadığı tezâhür etmiştir." 


\section{[21] Yedinci Fasıl - Yeni Câzibe Kanunu}

Şimdiye kadar Newton Nazariyyesi'nde pek müşevveş kalan ve hâdisât-1 sâire ile irtibatı görülemeyen bir hâdise de sath-1 arz üzerinde ecsâmın sükûtunu mûcib olan ve câzibe namıyla yâd edilen hâdisedir. Fi'l-vâki Newton Kanunu, iki cisim arasındaki câzibenin bu cisimlerin kütleleriyle mütenâsib olduğunu iddia etmektedir. Hâlbuki kütle-i ecsâmın süratlerine tâbi bulunduğu biraz evvel izah edilmişti. Şu halde Newton Kanunu'nu tatbik ederken ecsâmın hâl-i sükûnetindeki kütlesini mi yoksa hâl-i hareketindeki kütlesini mi telakkî etmek lazım gelecek?

Aynştayn, Newton Kanunu'ndaki bütün bu müphemiyetleri izâle ederek câzibenin kuvvet mâhiyetinde olmayıp bir nev`-i hareket-i mütezâyideye muâdil ve telakki olunan mekânın bir hassa-i mahsûsasından ibaret bulunduğunu göstermeğe muvaffak olmuştur. Şöyle ki: Eğer câzibe bir kuvvet olsa idi muhtelif kütleyi hâvî ecsâma ihrâz ettirdiği süratler de muhtelif olurdu. Hâlbuki bilumûm ecsâmın halâda ayn[1] süratle sükût eylediği ve mesela bir çeki sıkletinde, bir kaya parçasıyla bir kuş tüyünün halâda birlikte düştüğü ve her ikisinin de bir saniyedeki tezâyüd sürati takrîben 10 metre olduğu malumumuzdur.

Bir de bu kanunda dâhil-i hesab olan mesafe hangi râsıda göre telakki olunacak? Zira mesafenin de izâfi bir şey olduğunu biliyoruz. Diğer taraftan kuvve-i câzibenin sürat-i intişârı ziyâ süratine müsâvi mi yoksa büsbütün başka bir kıymeti mi hâiz! Yakın zamanlara kadar câzibenin ziyâ süratinden efzûn bir süratle intişâr eylediği iddia olunuyordu. Hâlbuki İzâfiyyet Nazariyyesi, câzibenin ziyâ süratiyle intişâr eylediğini ispat ve tecrübe de bunu teyît etmiştir.

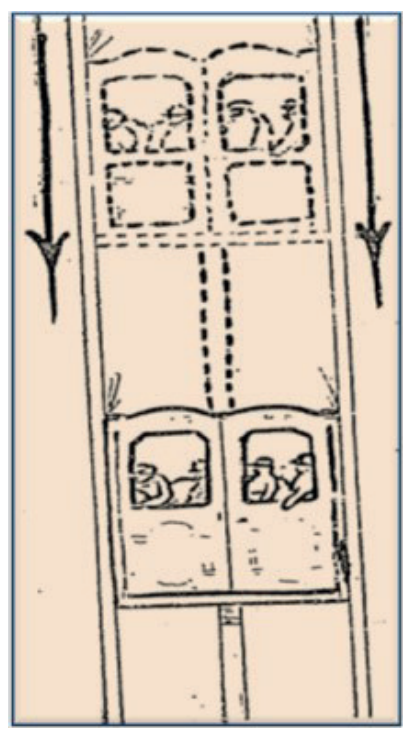

Şekil 4.

[22] Câzibenin bir hareket-i mütezâyideye muâdeleti şu tecrübe ile gösterilebilir: Bir asansöre râkiben bir binanın yukarıki katlarından zemin katına süratle inerken sıkletimizin tenâkus eylediğini ve ayağımızın asansör döşemesine daha dûn bir tazyîk icrâ eylediğini hepimiz pek güzel hissederiz. Asansör, dûn bir süratle ineceği yerde ecsâmın halâ' daki sükûtu gibi yani saniyede takriben 10 metreye müsâvi mütezâyid bir süratle nüzûl ederse içindeki yolcular artık ayaklarının döşeme üzerine hiçbir tazyîk icrâ eylemediğini hissedecekler; zira kendileri de asansörün süratini hâiz bulunacaklar.

Cepleri kurşunla bile dolu olsa bu madenin de veznini gâib etmiş olduğunu müşâhede ederler. Ceplerindeki kurşunu evlerimizde erzak tarttığımız yaylı mikyâs-ı kuvvetle tartmağa teşebbüs etseler bulacakları vezn sıfır olur. Ellerindeki çanta veya şemsiyeyi boşluğa bıraksalar bu eşyalar, gerek asansör dâhilinde ve gerek dişarıda asansör süratiyle sükût 
[23] edeceğinden kendilerine nazaran hareketten muarra yani câzibenin tesirinden âzâde bulunduğuna kâni olurlar (Şekil 4). Demek oluyor ki her nerede olursa olsun câzibenin tesirâtı zâhirî ve mütezâyid bir sürati hâiz bir râsıda nazaran tamamen kâbil-i izâle mâhiyeti hâiz!

İşte Aynştayn, bu suretle câzibenin bir hareket-i mütezâyideye muâdeletini göstermiş ve buna "muâdelet kaide-i esasiyesi" namını vermiştir.

Bu muhakemeye istinâden Newton tarafindan mevcudiyeti iddia olunan kuvve-i câzibe reddedilip de kâinatı teşkil eden dünyaların fezâda serbestçe hareket eden birtakım ecsâmdan başka bir şey olmadığı düşünülürse bu cisimler hareketleri esnasında kendilerine en suhûletli gelen tarîk hangisi ise onu intihâb edecekleri neticesi istihrâc olunur. Bu tarik-i eshel, fezânın maddeden pek ba 'îd bulunan aksâmında bi’t-tabi ' bir tarîk-i müstakîmdir. Fakat ecsâm-1 maddiyye civarında, bu tarîk-i eshelin kesb-i inhinâ eylediğini ecrâm-1 semâiyyenin hareketini tetkîk ederek anlıyoruz.

Demek oluyor ki azîm kütleler civarındaki tarîk-i eshel, yani iki nokta beynindeki yolun en kısası, bir hatt-1 müstakîm değil, fakat riyâziyyâtta "münhani-i asgar" tesmiye olunan bir hattır.

Nitekim ki kapudanlar [kaptanlar] dahi, sath-1 bahr üzerinde en kısa tarîki intihâb etmek mecburiyetinde bulunduklarından faraza Lizbon'dan hareketle Nevyork'a giderken doğruca garp istikametini takip etmezler. Bir küre üzerinde bulunan iki nokta beynindeki mesafenin en kısası nikat-i mezkûreden geçen bir daire-i kebire olduğundan Lizbon'dan hareket ederken biraz şimâl-i garbî ve Nevyork'a müvâsalat ederken de şimâl-i şarkî istikametini takip ederler.

Bu izâhât üzerine Aynştayn'ın câzibe kanunu şu suretle ifade edebilir: [24] "Kendi haline serbestçe terk edilen her cisim, fezâda bir münhani-i asgar takip eder."

Bu münhani-i asgarın bir hatt-ı müstakîmden ibaret olmaması iki nokta beynindeki en kısa yolun bir hatt-1 müstakîm olduğunu kabul eden, Öklid tarafindan tesîs ve mekteplerimizde tedrîs edilen hendesenin de hakîkate muvâfık olmadığını gösteriyor.

Mütâlaât-1 sâlifeye istinâden Aynştayn, câzibeyi, azîm kütleler civarındaki mekânın bir hassa-i mahsûsası olmak üzere telakki etmiş ve bu aksâmda mekân-1 hakikinin inhinâli bir mekân olduğu neticesine vâsıl olmuştur.

Aynştayn, İzâfiyyet Nazariyyesi’ne istinaden şimdiye kadar üç mühim hâdisenin vukûunu evvelden keşfetmiştir:

1. Ziyânın hâiz-i vezn olması

2. Utârid namındaki seyyarenin kapalı bir münhani resmetmemesi

3. Ziyâ-yı Şems tayfindaki çizgilerin kırmızıya doğru tebeddül-i mekân eylemesi. 


\section{[25] Sekizinci Fasıl - Ziyânın Vezniyyeti}

Aynştayn Nazariyyesi'nin en câlib-i merak ciheti, hiç şüphe yoktur ki ziyânın vezniyyetini meydan-1 sübûta vaz' eden kısmıdır. Fi'l-vâki bir ihtizâzdan ibaret olan ziyanın hâiz-i vezn olabileceğini tasavvur etmek malumât-1 sâbıkamıza tevâfuk etmeyen hususâttandır. Mesele şu surette tetebbu' edilebilir: İçi boş bir cisimden bir şuâ-i ziyâi veya harûrinin mürûr ettiğini farz edersek bu cismin kütlesi, bir taraftan kütle-i maddiyyesi ve diğer taraftan da boşluğu, derunundaki şu'âın kütlesinin mecmû‘una müsâvi olur. İmdi bir terazi ile bu cismin vezni takdîr edildiği halde hâvi olduğu kudret-i minşe'a hasebiyle vezninin tezâyüd eylediği müşâhede edilirse ziyânın hâiz-i vezn olduğu anlaşılmış olur. Fakat bu derece hassas bir terazi bulunamayacağından ziyânın hassa-i vezniyyeti, şu'ââtın câzibe tesiriyle kısmen kütle-i maddiyye tarafina doğru bir hareket ahz etmesi yani dûçâr-1 inhinâ olmasıyla sabit olabileceği derkârdır.

Newton Nazariyyesi bu inhinânın sebeb ü hikmeti hakkında bize hiçbir fikir vermediği halde Aynştayn Nazariyyesi bu hâdiseyi tenvîr ve miktar-1 inhirâfı da meydan-1 sübûta vaz‘ etmektedir.

Eğer hakîkaten ziyânın bir vezni ve bir kütlesi var da bu iki kıymet arasındaki nisbet madde hakkında câri olan kanun nisbetine müsâvi ise Aynştayn Nazariyyesi mûcibince sath-1 arz civarında ufkî bir şuâ-i ziyâînin birinci saniyenin nihayetinde 10 metre sükût etmesi yani ufkıyyen intişâr eden bir şu'â-i ziyâînin bir saniye zarfında kat eylediği 300.000 kilometrelik mesafenin iki uçları beynindeki tefâvüt-i irtifâ‘'1n 10 metreye müsâvi olması lazım gelir. [26] Bu kadar büyük mesafelere ait tecrübelerin sath-1 arz üzerinde icrâsı mümkün olmadığından Aynştayn, tecrübe sahasını Güneş'in civarına nakletmeğe mecbur olmuştur. Fi'l-vâki Güneş'in etrafındaki câzibe, küre-i arzın etrafındaki câzibeden 27 defa daha büyük olduğu gibi Güneş'in hâiz olduğu eb âdın azameti hasebiyle de saha-i câzibesinin tesirine daha uzun bir şuâ-i ziyâî arz etmek mümkündür.

Şuâ-i ziyâi bir vezniyyeti hâiz ise bu iki nokta-i nazar dolayısıyla ihrâz edeceği inhirâfın bir derece saniyesi kadar olması lazım gelir ki bu da heyet-şinâsân tarafından sıhhat-i azîme ile mesâha olunan bir kıymettir. 


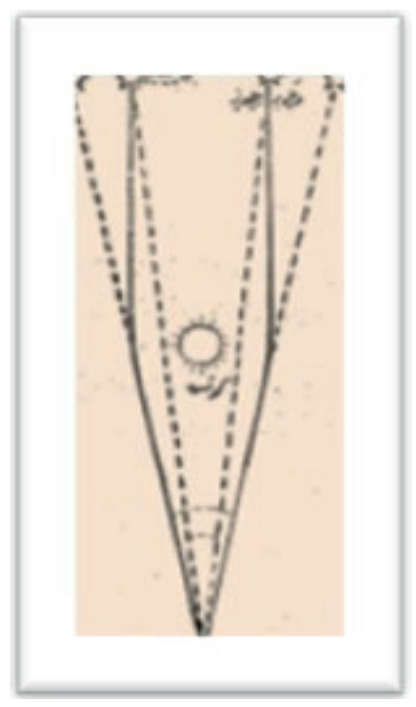

Şekil 5.

İşte (Şekil 5) uzaklarda bulunan bir yıldızdan sâdır olup Güneş'in civarından geçerek arza gelen bir şuâ-1 ziyâîyi irâe eder. Bu şu'ânın en ziyade dûçâr-ı inhinâ olması lazım gelen kısmı, Güneş'in câzibe sahasına marûz olan kısmıdır. Dûrbîne ve buradan gözümüze vâsıl olan şu'â-i ziyâînin istikameti temdîd olundukda râsıd, yıldızın bu istikamette yani noktalı hatt-1 müstakîm ile gösterilen tarafinda bulunduğunu zanneder. İşte bu suretle yıldızın vaziyet-i hakikiyyesiyle vaziyet-i zâhiriyyesi arasındaki farkın şu'â-i ziyâînin miktâr-1 inhirâfına müsâvi olacağı anlaşılıyor.

Şuâ-i ziyâînin bu inhirâfı bi’t-tabi‘ Şems'in yakınında görülen yıldızlar hakkında vârid olmak lazım gelir. Ziyâ'-1 Şems, yıldızların ziyâsını setr ettiğinden şu halde [27] tecrübenin ancak bir küsûf esnasında yani Kamer'in Güneş'le arz arasına gelip de ziyâ-1 Şems'i setr eylediği zaman icrâsı mümkün ve ancak ve bu suretle Güneş'in yakınında birtakım yıldızlar kâbil-i mer'̂̂ olur. İmdi bu yıldızların Güneş’ten mümkün olduğu kadar uzak diğer sabit yıldızlara nazaran vaziyeti, Güneş civarında bulunmadıkları zaman fotoğraflarının ahzı suretiyle tayin eylediği halde bir kerede Güneş'in yakınında bulundukları zaman küsûf esnasında fotoğrafları alınarak aynı sabit yıldızlara göre vaziyetleri tayin edilirse bu iki fotoğrafının birbiri üzerine tatbîk ve mukayesesi suretiyle miktar-1 inhirâfı tayin etmek mümkün olurdu.

Eğer Aynştayn'ın iddiası vechile ziyâ bir vezni hâiz ise bu fotoğraflar ziyanın inhirâfını gösterecek ve İzâfiyyet Nazariyyesi doğru ise fotoğrafların mukayesesinden istihrâc olunan miktar-1 inhirâfın da Aynştayn'ın bil-hisâb irâe eylediği miktar-1 inhirâfa müsâvi olması lazım gelir.

Bu tecrübenin icrâsı için bâlâda arz eylediğim vechile bir küsûf husûle gelmesine intizâr etmek lazım geliyordu. Zira ahvâl-i âdiyede ziyâ-1 Şems yakınında bulunan yıldızları görmeğe müsâit değildir. Diğer taraftan küsûf esnasında da Güneş'in yakınında parlak yıldızların bulunması da lazım gelirdi. Pek büyük bir tâli‘ eseri olarak 1919 senesi Mayıs'ının 29'uncu günü yani tam üç sene mukaddem bu tecrübelere pek müsait bir küsûf-1 tam husûle geleceği 1917 senesinde anlaşılmıştır. Bu hâdisenin pek büyük bir eser-i tâli‘ olduğunu arz ediyorum. Zîrâ, Aynştayn dünyaya başka bir tarihte gelmiş olsaydı böyle muvâfik bir küsûfun husûlü için belki binlerce sene beklemek lazım gelirdi.

[28] Bu müstesna fursattan bil-istifade İngiltere'nin en maruf heyet-şinâsânından mürekkeb bir heyet-i fenniyye teşkil ve bunlara îcâb eden âlât-1 rasadiyye terfîk edilerek havanın bozukluğundan dolayı rasadâtın icrâsına mâni-i zuhûr ihtimalini tenkîs için bu heyetlerden 
biri Brezilya'nın şimâlinde kâin Subral'e, diğeri de Afrika'nın garbında bulunan Prens [29] Adası'na i‘zâm edilmişlerdir. Subral'de tesis edilen âlât-1 rasadiyye (Şekil 6)'da görülüyor.

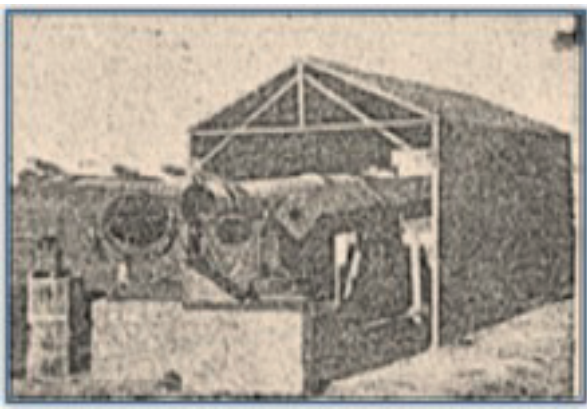

Şekil 6.

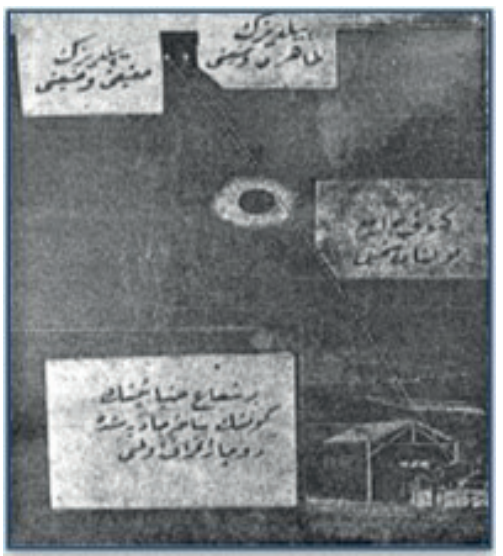

Şekil 7.

Her iki heyet-i fenniyye tarafından küsûfun devamı müddetince (Şekil 7) alınan müteaddid fotoğraflarla birkaç mâh-1 mukaddem, Güneş henüz bu yıldızlardan uzak bulunduğu halde alınan fotoğrafiler birbiriyle mukayese edildikte Aynştayn tarafından İzâfiyyet Nazariyyesi’ne istinaden tayin edilen inhirâf-ı ziyâ miktarının bu rasadâtta istihsâl olunan inhirâf miktarına müsâvi olduğu sabit olmuştur.

İngiltere'nin en büyük heyet-şinâsânından mürekkeb iki heyet-i fenniyyenin istihsâl eylediği bu netice, Aynştayn Nazariyyesi'ni te'kîd edince bu nazariyyenin mukârin-i hakîkat olduğu bi’t-tecrübe dahi anlaşılmış oluyordu. İşte bu netice-i tecrübiyyedir ki İzâfiyyet Nazariyyesi'nin ehemmiyet-i hakikiyyesini âlem-i beșere ilan etmiştir.

\section{[30] Dokuzuncu Fasıl - Utârid'in Kapalı Bir Güzergâh Resmetmediğinin İzahı}

Aynştayn Nazariyyesi'nin şu âât-1 ziyâiyyenin inhirâfı tecrübesiyle te'kîd olunduğunu bâlâda izah eyledik. Şimdi de bu nazariyyenin diğer bir te'kîdinden bahsedeceğiz.

Bir şu'â-i ziyâiyyenin saniyede 300.000 kilometro [kilometre] gibi bir sürat-i azîmeyi hâiz olması sayesinde birkaç dakika zarfında kâinatın mühim bir kısmını dolaşarak geçtiği yerler hakkında bize malumât-1 müfîde getirdiğini gördük. Fakat velev dûn bir süratle olsun asırlardan beri fezâda seyr-i tabîisini takip eden seyyârât dahi güzergâhlarını devrettiklerinin her defasında fezânın evsâfı hakkındaki malumâtımızı tezyîde hâdim bulunduklarında şüphe yoktur. 
Cümlenin malûmudur ki Newton Kanunu, seyyârâtın Güneş etrafındaki hareketlerinde kapalı bir münhani resmettiğini iddia eder. Beyziyyü’ş-şekl olan bu münhaninin ismine lisan-1 hendesede "kat"-1 nâkıs" derler. Uzunluğuna kesilen bir limonun muhîti bu şekle pek müşâbihtir. Civarda bulunan diğer bir seyyare bu hareketi ihlal etmediği takdirde Newton Nazariyyesi bu münhaninin lâyetagayyer olacağını gösterir.

Hâlbuki yeni câzibe kanunu mûcibince seyyârâtın fezâda resmettiği mahrek mesdûd olmayacak yani seyyâre mahrekini resmettiği zaman her devrini müteakip aynı noktaya vâsıl olmayacak! Seyyâre demin tasavvur edilen kesik limon muhîtini resmederken güya bu limonun da masa üzerinde yavaşça dönmesi gibi bir hareketin daha mevcudiyeti Aynştayn tarafından iddia edilmiştir. Miktar-1 deveran pek cüz'î olmakla beraber Aynştayn bunu bi'lhisab tamamen tayine muvaffak olmuştur.

Mahrekin bu hareketi bilhassa uzunca limon şeklinde olan mahreklerde ve sürat-i seyirleri nisbeten büyük olan seyyârelerde hissolunacak raddede bulunacağını İzâfiyet Nazariyyesi ispat etmektedir.

[31] Bu iki şartı hâiz seyyareler miyânında Utârid'in bilhassa bu nev'-i hareketinin en fazla olacağı tahmin olunuyordu. Bu hareketin Newton Kanunu ile izahı mümkün olamayınca mukaddema en marûf heyet-şinâslardan (Löverrie) [Le Verrier] Utârid'in bu suretle câzibe kanununa tevâfuk etmeyen hareketinin ancak Utârid'in arka tarafinda vâki' diğer bir seyyarenin mevcudiyetiyle kâbil-i izah olduğunu iddia etmiş; hatta bu müz'ic seyyareyi de Vulcain namılla tevsîm etmiştir.

Dünyanın bütün heyet-şinâsânı bu yeni seyyarenin zuhuruna intizâren, a'mâk-1 fezâyı defaatle tarassud etmişlerse de bütün bu tarassudât beyhude bir emekten ibaret kalmıştır. İşte Newton'un câzibe kanunu dûçâr-1 akâmet olmuştu.

Aynştayn ise İzâfiyyet Nazariyyesi'nden istihrâc eylediği câzibe kanunuyla bu muammayı tamamen halletmiştir. Fi'l-vâki' Aynştayn, Utârid'in mahrekinin bir asır ne kadar deveran edeceğini bil-hisâb tayin etmiş ve bu miktar ise tarassudât-1 hey'iyyeden istihrâc olunan miktara tamamıyla müsâvi bulunmuştur.

İşte bu tecrübeler dahi Aynştayn Nazariyyesi'ni tekîd ederek hakîkate muvâfık olduğunu meydan-1 sübûta koymuştur.

\section{[32] Onuncu Fasıl - Ziyâ-ı Şems Tayfındaki Çizgilerin Kırmızıya Doğru Tebdîl-i Mekân Eylemesi}

Aynştayn tarafından tesîs olunan câzibe kanunu mûcibince bir saha-i câzibenin şiddeti tezâyüd ederse bu sahada vukûa gelen bir hâdise-i muayyenenin müddet-i devamı da tezâyüd eder. Mâdem ki Güneş civarındaki câzibe, küre-i arzın câzibesinden 27 defa daha şiddetlidir; şu halde muayyen bir zerrenin Güneş üzerindeki müddet-i ihtizâzı sath-1 arz üzerinde 
bulunan aynı zerrenin müddet-i ihtizâzından efzûn olacak; binaenaleyh herhangi bir cism-i basitin ziyâ-1 Şems tayfındaki çizgilerinin tûl-i mevcleri de arz üzerinde bulunan bir menba'-1 ziyâîden aynı cism-i basite ait tayfdaki çizgilerin tûl-i mevclerinden daha büyük olması yani kırmızıya daha yakın olması icâb eder.

Aynştayn'ın bu üçüncü iddiası da geçen sene bir taraftan Paris Politeknik Mektebi Fizik Muallimi Mösyö (Pero) [Alfred Perot] ve diğer taraftan Mösyö (Puisson) [Henri Buisson] ve Mösyö (Fabri) [Charles Fabry] nam hikmet-şinâsân tarafından bi’t-tecrübe ispat edilerek yeni nazariyyenin ehemmiyeti bir kat daha tezâhür etmiştir.

İşte Aynştayn, İzâfiyyet Nazariyyesi’nden istihrâc eylediği şu üç mühim neticenin de bi’ttecrübe sabit olması bu nazariyyenin hâdisât-ı kâinatı izah eden en mükemmel bir nazariyye olmak üzere telakki edilmek lazım geleceğini gösterir.

\section{[33] On Birinci Fasıl - Yeni Mekân - Zaman Mefhûmu}

Aynştayn Nazariyyesi'nin şimdiye kadar izah ettiğimiz ve malumât-1 sâbıkamızı alt üst edecek mahiyette bulunan netâyicine ilaveten bir de esâsât-1 felsefiyyede taalluku olmak itibariyle mekân ve zaman mefhumları hakkındaki kanaat-1 hâzırayı arz etmek isterim.

Malum olduğu üzere her müşâhede iki kısmı hâizdir: Birincisi müşâhidin şahsı diğeri de müşâhede olunan şey. Müşâhede eylediğimiz bir hâdise, yalnız bu hâdisenin mâhiyetine tâbi olmayıp aynı zamanda şahsımıza göre yani vaziyetimize, hareketimize ve diğer şahsî husûsâtımıza göre değişir. Ednâ bir mülâhaza kâinatın mahiyet-i hakikiyyesinin bizim tasavvurât-1 kâsırânemize göre değişmeyeceğini gösterir: Fil-vâki şu etrafımızda cereyan eden hâdisâtı, tetebbu ve mesâha etmek ve mesela bir tûlü ölçmek veya bir müddeti takdîr etmek için, hâdisât-1 mezkûrenin gerek mekân ve gerek zaman itibariyle vücûda getirdiğimiz keyfî birtakım taksimat ile mukayesesini icrâ eyleriz. Hâlbuki tabiat, bu taksîmât ile hiç de alâkâdâr olmayabilir. Çünkü seyr-i tabîiyyesini kendi telakkimize göre tadîl etmek yed-i iktidârımızda değildir.

Şu halde hâdisâtın tetebbu için mekân ve zaman mefhumlarını nasıl tesis edeceğiz? Bunun için kitab-1 tabiatın yalnız bir sahifesini yani mahdûd bir kısmını tedkîk ile değil fakat mümkün olduğu kadar vâsi‘ bir kısmını tetebbu‘ etmekle nâil-i maksad olabiliriz.

İşte bu hakîkati teslim ettikten sonra evvel emirde mekânı tayin için istimâl [34] eylediğimiz ve mekteplerde öğrendiğimiz (Öklid)in tesîs-gerdesi olan âdi hendesenin ne dereceye kadar hakîkate tevâfuk etmekte olduğunu tedkîk etmek lâzımedendir.

Malumdur ki hendesede, hakîkat-i mutlaka olarak telakkî olunan birtakım kaziyyelere istinad olunur. Ez-cümle hakîkat olarak kabul olunan esaslardan biri, hatt-1 müstakîmin iki nokta arasında en kısa bir tarîk olmasıdır. Öklid hendesesinin istinâd eylediği esaslardan ikincisi de verilen bir müstakime bir noktadan ancak bir müvâzi-i müstakim resm 
olunabilmesidir. Efkâr-1 kâsırânemize pek tabi ve pek basit görünen bu faraziyeler acaba muvâfik-1 hakîkat midir?

Bir kere hayat-1 ameliyyede bir hatt-1 müstakîmi nasıl telakki ettiğimizi düşünelim: Bir mühendis arazi üzerinde muayyen iki nokta arasında bir hatt-1 müstakîm çizmek isterse mezkûr noktalara flama tabir olunan iki değnek rekz ederek göz ile bu iki değnek kenarlarına birden bakar. Bu şu'â-i ziyâîyi müstakîm itibar ederek buna tetabuk ettirdiği bir çizginin müstakîm olduğuna kanaat getirir. Hâlbuki tecrübe yıldızlardan bize gelen ziyânın bir saha-i câzibe derûnundan mürûru halinde dûçâr-1 inhirâf olduğunu gösteriyor.

Şu halde içinde yaşadığımız kâinata göre tedrîs olunan hendesenin yanlış kaziyyelere istinad eylediği ve hakîkate muvâfık bir hendese olmadığı anlaşılıyor. Kezâ "bir müstevî dâhilinde bulunan iki hatt-1 müvâzi yekdiğerini katetmez" dediğimiz zaman bunun da hakîkate tevâfuk etmediğini tecrübe gösteriyor. Zira bir müstevî dâhilinde tasavvur edilen iki şu'â-i ziyâînin ecrâm-1 semâiyyenin câzibesiyle muhtelif miktarlarda dûçâr-1 inhinâ olduklarını tecrübe gösteriyor. Şu halde müvâzî kalmalarına imkân olamaz.

Diğer mühim bir mesele de iki nokta arasındaki mesafenin bir cetvel ile mesâhası meselesidir. Bu mesâha, tûl-i mi ‘yârı ittihâz olunan bir cetvelin iki nokta arasında hareket ettirilmesiyle ve bu mesafede kaç defa dâhil olduğunu tahkîk etmekle icrâ ediliyor. Fakat istihsâl olunacak netice, bu iki noktanın yekdiğerine nazaran ve râsıda [35] göre bir hareketi hâiz olup olmamasıyla da değişir. Çünkü bir râsıda göre harekette bulunan bir tûlün hareket istikâmetine göre kısaldığı biraz evvel izah edilmişti.

Şu hâle göre bir tûlü ölçmek, bir sürati ölçmekle müterâdif oluyor. Hâlbuki bir sürati takdîr etmek için mesafe ile zamanın takdîri şarttır. İşte buradan anlaşılıyor ki tûl mesâhâtinden zamanı büsbütün tefrîk eden Öklid hendesesi, hakikî hendeseye tevâfuk etmiyor. Hâlbuki zamanı da tûl, arz ve umk mefhumlarına rapteden yani tabir-i fenniyyesiyle dört bu'dlu bir hendesenin tabiata en muvâfik bir hendese olacağı anlaşılıyor.

Bu hâkîkati, Alman riyâziyyûnundan olup pek genç yaşında terk-i hayat eden (Minkofski) [Minkowski] Kolonya şehrinde 1908 senesinde îrâd eylediği meşhur konferansında ilan ederek demiştir ki: "Ba'de-mâ mekân ve zaman mefhumlarının müstakilen telakkisine imkân kalmamıştır. Hakîkati ancak bu iki mefhumun imtizâcında aramalıyız.”

El-hâsıl tecrübe gösteriyor ki şu içinde yaşadığımız kâinat, Öklid hendesesinde iddia olunduğu gibi üç bu'dlu değil, fakat mekân ve zaman mefhumlarının imtizâcından mütevellid dört bu'dlu bir mekân-zaman kâinatıdır. Dördüncü bu'd ise eski mefhumumuzdaki zamandır.

Mekânı zamandan ve zamanı mekândan ayırmak imkânı olmadığı ve bu sûret-i telakkînin ne derece mukârin-i hakîkat olduğu basit bir misal ile de tenvîr edilebilir: Bayezid 
Meydanı'ndaki bir kaldırım taşını kırmızıya boyamak suretiyle bulunduğu mevkii tespit edelim. Bu taşın üzerinden geçerek ders dinlemeğe gelen bir talebe dersin hitâmını müteâkip evine avdet ederken yine bu taşa basacak olursa acaba bu efendi muhtelif zamanlarda aynı taşın üzerinde iken kâinatın da aynı noktasını mı işgâl ediyor? Buna verilecek cevap, bir cevab-1 menfî̀en başka bir şey değildir. Çünkü bu taşın üzerine ilk defa bastığı an ile ikinci defa bastığı an arasında güzerân olan müddetin her saniyesi zarfında, arz-1 fezâda otuz kilometre mesafe katetmiş [36] olacağından Güneş’te bulunan bir râsıda göre her iki vaziyetin bir olmayacağı tabîidir.

İfademizden bir mana istihrâc edebilmek için zamandan bahsedildi mi mekânı da tayine mecburuz. Üç asır evvel vukua gelen bir zelzeleden bahsedilirse bundan hiçbir mana istihrâc edemeyiz. Zira bu hâdisenin Güneş’te mi, Kamer'de mi, arzda mı husûle geldiğine dair bir fikrimiz olamaz.

El-hâsıl zaman ve mekân yekdiğerinden kâbil-i tefrîk olmayıp râsıda göre mütehavvil ve şu içinde yaşadığımız kâinatın dört bu'dlu bir mekân-zaman kâinatı olduğu Aynştayn Nazariyyesi îcâbındandır.

\section{[37] On İkinci Fasıl - Kâinatın Mütenâhi Fakat Hudutsuz Olması}

Kâinat mütenâhi mi yoksa nâmütenâhi mi? İşte öteden beri fikr-i beşeri işgal etmiş olan bir mesele-i mühimme!

Kâinat nâmütenâhi denildiği zaman bundan istihrâcı lâzım gelen mana şudur: Eğer önümdeki istikâmete doğru ebediyyen yürüyecek olursam hiçbir zaman nokta-i azîmete avdet etmeğe muvaffak olamayacağım! Acaba buna imkân var mı? Newton'a göre mesafe yani mekân ihtiva eylediği ecsâma yıldızlar adedine tâbi‘ olmayarak nâmütenâhî vüs'ati hâiz olabileceği cihetle bu faraziyye daire-i ihtimal içindedir. Fakat Aynştayn'a nazaran maddeden ve kudretten muarra bir mekân tasavvur edilemediği gibi mekân maddenin gayr-i kâbil-i iftirâk bir hassası olarak telakkî edilmektedir.

Hâlbuki icrâ kılınan tarassudât-1 hey'iyye Güneş’ten tebâüd edip kehkeşânın hududlarına takarrüb ettikçe, vâhid hacîmdeki yıldızlar adedinin gittikçe tenâkus eylediğini gösteriyor. Kehkeşânın öte tarafı yıldızlardan muarrâ bir halde görünmektedir. Ve daha ötede ise helezoniyyü'ş-şekl birtakım sehâbiyyeler müşâhede olunuyorsa da kevâkib adedinin mahdûdiyyeti yine tezâhür ediyor.

İşte bu müşâhedât ecrâm-1 semâiyyenin mahdûdiyyetini îmâ etmekte olduğundan madde haricinde bir mekân kabul etmeyen Aynştayn Nazariyyesi, mekânın nâmütenâhi olmayacağını tahmin etmektedir. Şu hâle nazaran kâinatın hududu var mı? Var ise nasıldır? Nâmütenâhî ve hudutsuz bir şey tasavvur olunabilir mi? 
Sath-1 arz gibi kürevî bir satıh üzerinde yürüyen bir şahıs telakkî edilirse [38] şahs-1 mezkûrun muhtelif istikametlerde tebdîl-i mekân eylediği halde hiçbir hududa vâsıl olamayacağ1 tabîdir. İşte bir sath-1 kürevî bu itibar ile hem mütenâhî hem de hudutsuz bir mekâna misaldir. İki bu'dlu bir mekâna müteallik şu misale müşâbih olarak üç bu'dlu bir mekânın mevcudiyyetini ve bu üç bu'dlu mekân hacminin mütenâhî fakat hudutsuz olacağını Alman meşâhir-i riyâziyyûnundan (Reyman) [Riemann] ispat etmiştir.

İmdi câzibe-i umûmiyyenin yeni tarz-1 telakkisine göre kâinatın Öklid'in tasavvurâtına tevâfuk etmediği ve inhinâli bir mekân-zamandan ibaret olduğu izah edilmişti.

Yıldızların fezada muntazam bir tevezzü‘ü hâiz bulunduğu bir an için kabul edilirse bu tevezzü“ miktarının pâyidâr kalması şartı bi’l-riyâza taharrî olundukda (mekânın sabit inhilâli olması ve adeta bir sath-1 kürevî gibi kendi üzerine kapanması) lazım geleceği neticesi istihsâl olunmaktadır. Bu mütenâhî ve hudutsuz kâinat içinde intişâr eden bir şu'â-i ziyâînin ilâ gayri‘n-nihâye devredeceği anlaşıllyor.

Kehkeşânın ihtivâ eylediğini takriben bildiğimiz madde miktarına istinaden Aynştayn, İzâfiyyet Nazariyyesi iânesiyle inhinâlı olan kâinatın nısf-1 kutrunu da hesab etmiş ve bu nısf-1 kutrı ziyânın 150 milyon sene zarfinda kat edeceğini bulmuştur. Şu hesaba göre bir şu'â-i ziyâî kâinatın çevresini devr edebilmek için lâ-akall 900 milyon senelik bir zamana arz-1 iftikâr edeceği ve bu erkâmın bazı rasadât-1 hey’iyyeye tevâfuk eylediği anlaşılmıştır. Maa-zâlik bu rasadâtın katiyyeti ancak mürûr-1 zamanla tahakkuk edebileceği de nazardan dûr tutulmamak lâzım gelir.

\section{[39] On Üçüncü Fasıl - Aynştayn Nazariyyesinin Hayat-ı Ameliyyeye Tesiri}

Aynştayn Nazariyyesi hakkındaki izahatımı takip etmek lütfunda bulunduktan sonra kariîn-i kirâm pek tabî‘ olarak şu suâli îrâd etmek isterler: "Acaba Aynştayn Nazariyyesi’nin hayat-1 ameliyyemize tesîri nedir?" Heman arz edeyim ki hayat-1 ameliyyeye bu nazariyyenin hiç tesiri yoktur. Fakat hayat-1 ameliyyeye bu nazariyyenin hâiz-i tesir olmaması kıymetini tenkîs edecek mahiyette midir? Katiyyen.

Aynştayn, bu nazariyyesiyle bize derûnunda yaşadığımız şu kâinatı daha iyi tanıtmak, kitab-1 tabiatı esâsât-1 kuvviyye ile mücehhez olarak tedkîk etmek imkânını vermiştir. İnsanlar vücuda getirecekleri binâ-yı ilmi muhkem temellere istinad ettirmezlerse taharri-i hakîkat hususunda sarf edecekleri himmet işte şimdiye kadar olduğu gibi inhidâma mahkûm olur. Bir mimar inşâ edeceği binanın istinad edeceği arsayı müstevî addeder. Binayı inşâ ettirirken duvarların şakûliyyetini temîn için istimâl edilen şakulların hep birbirine müvâzî olduğunu kabul eder. 
İşte bir mimar, her mütefekkir gibi arzın kürevî olduğunu bildiği halde bir bina inşâ ederken bu malumâttan katiyyen istifade etmez. Arsayı müstevî addettiği gibi binayı inşâ ettirirken kullanılan şakulların birbirine tamamen müvâzî olduğunu kabul eder. Acaba bir mimarın hayat-1 ameliyyesine icrâ-yı tesir etmiyor diye arzın küreviyyeti gibi hâiz-i ehemmiyet bir malûmâtı inkâr etmek mi lazım gelecek!

İşte Aynştayn Nazariyyesi'nin de hayat-1 ameliyyemize tesiri, hakîkat itibariyle bir mimara [40] göre arzın küreviyyeti raddesindedir. Bu itibar ile pek basit olan ve hayat-1 ameliyyede sıhhat-i kâfiye temin eden Newton Kanunu'yla Öklid hendesesini, müdâviminini hayat-1 ameliyyeye ihzâr ile mükellef olan mekâtib-i ibtidâiyye ve tâliye tedrîsâtından tayy etmeğe mahal yoktur. Fakat İzâfiyyet Nazariyyesinin Dârü'l-fünûn tedrisâtında ve betahsîs ilm-i heyetle esâsât-1 felsefiyyede ehemmiyet-i azîmesi gayr-1 münker olduğundan bu seneden itibaren Dârü'l-fünûnumuzda da umûmi fizik dersinde bu nazariyyenin tedrîsi muvâfik görülmüştür. Maa-zâlik, şimdiye kadar kâinat hakkındaki malûmâtımız hakîkate tevâfuk etmeyen mekân, zaman ve kütle mefhumlarına müstenid idi. Aynştayn, ummân-1 cehâletimizi nur-1 hakîkat ile tenvîre muvaffak olmuştur. Sa'yi meşkûr olsun.

\section{[41] Dârü'l-fünûn Umûmî Fizik Muallimi Meclis-i Kebir Maarif Azasından Mehmet Refik Bey’in Âsâr-ı İlmiyyesi}

1. Aynştayn Nazariyyesi:Umûmun anlayabileceği bir sûrette izah edilmiştir. Fiyatı 25 kuruştur.

2. Nazarî ve Amelî Fenn-i Elektrik ve Tatbikat-1 Sanaiyyesi - Elektrik fenninin ve tatbikat-1 muhtelifesini basit bir surette izah etmek üzere kaleme alınan işbu eser 600 sahife ve 600 şekli ihtiva eder. Fiyatı: 150 kuruştur.

3. Harâret ve Harâret-i Mihânikiyye: Mevcudu kalmamıştır.

4. Tatbikat-1 Elektrikiyye Dersleri: Mevcudu kalmamıştır.

5. Amelî ve Tecrübî Hikmet-i Tabiîyye - Mekâtib-i Sultâniye’ye mahsus olup derdest-i tab'dir.

6. Elektrikiyyet ve Miknatısıyyet - Fen Medresesi Dersleri. Der-dest ikmâl olunan bu eser üç ciltten mürekkep olacaktır: Cild-i Evvel: Elektrikıyyet ve Mıknatısıyyet. Cild-i Sâni: Gazât Derûnunda İfrâgât-1 Elektrikıyye ve Faaliyet-i İnşiâiyye. Cild-i Sâlis: Maksvel [Maxwell), Elektron ve İzâfiyyet Nazariyyeleri

7. Ziyanın Mâhiyeti-(Fransızcadır.) Muallim Maks Plank [Max Planck] eserinin Fransızcaya tercümesi. Doktor Kerim Bey’in muâvenetiyle tahrîr olunmuştur. 


\section{SÖZLÜK}

âlât-ı rasadiyye: gözlem aletleri

âlem-i beşer: insanlık âlemi

a'mâk-ı fezâ: uzayın derinlikleri

amûdî (a.zf.): dik olarak

atâlet (a.i.): hareketsizlik, durgunluk

batî (a.s.): yavaş, ağır hareketli

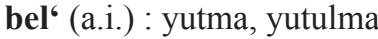

beyzîyyü'ş-şekl: oval, yumurta şeklinde

bil-hisâb (a.zf.): hesaplayarak

bu'd (a.i.): boyut

câzibe kanunu: çekim yasası

câzibe-i umumiyye: genel çekim [yasası]

ecrâm-ı semâiyye: gök cisimleri

ecsâm (a.i.): cisimler

ecsâm-ı sagîre: küçük cisimler

esîr: fizikte bir terim, esir maddesi

faraziyye (a.i.): varsayım, hipotez

fezâ (a.i.): uzay boşluğu

gazât (fr.i): gazlar

hâdisât-ı hikemiyye: fiziksel olaylar

hâdisât-ı mütenevvia: çeşitli olaylar

hâiz-i vezn: ağırlığa sahip

halâ' (a.s.): boş, boşluk hâl-i tevakkuf: durgun, durma hâli

hamûle-i elektrikiyye: elektrik yükü

harûri (a.s.): hararetle ilgili

hatt-ı müstakîm: doğru çizgi

hatt-ı müvâzi: paralel çizgi

hesâbât-ı tavîle: uzun süren zahmetli hesaplar

heyet-i fenniyye: teknik kurul

heyet-şinâsân (a.f.b.i): astronomlar

heyulâ (a.i.): madde, töz, eşyanın gerçeği

hikmet-şinâsân (a.f.b.s.): fizikçiler

huzme-i ziyâiyye: 1 șı 1 șını

ilâ gayri'n-nihâye (a.zf.): sonsuza kadar imtizâc-ı kimyevî: kimyasal birleşme

inşiâ (a.i.): ışınım

izâfiyyet (a.i.): görelilik

kâbil-i mer'î: gözetlenebilir

kamer (a.i.): Ay

kat'-1 nâkıs: elips

kaziyye (a.i.): önerme, yardımc1 teorem

keh-keşân (f.b.i.): samanyolu

kemmiyyet (os.i.): nicelik, adet, say1

kevâkib (a.i.): yıldızlar 
kuvve-i câzibe: çekim kuvveti

küsûf (a.i.): Güneş tutulması

kütle-i ecsâm: cisimlerin kütlesi

lâ yetagayyer (a.b.s.): sabit, değişmez

madde-i mahsûsa: özel madde

mâh-ı mukaddem: önceki ay

makarr (a.i.): merkez

malûmât-ı fenniye: fen bilgisi

menba'-1 ziyâ: 1şık kaynağı

mesâha (a.i.): ölçme

meşâhir-i riyâziyyun: meşhur matematikçiler

meydan-ı sübût: sabit olma, gerçekleşme

mihânik (a.i.): mekanik

miktar-ı inhirâf: sapma miktarı

mikyâs (a.i.): ölçü aleti, ölçek

minşe'a (a.i): mekik, (mekik dokumaktan mecazen iki yer arasında kesintisiz gidip gelmek)

mi'yâr (a.i.): ölçü

muâdelet (a.i.): eşitlik, eş değerlik

muâdelet kaide-i esasiyesi: eşdeğerlik temel kuralı

münhani (a.s.): eğri

münhani-i asgar: en küçük eğri

müselles-i kâimü'l-zâviye: dik üçgen müstevî (a.s.): düzlem

müteharrik (a.s.): hareket eden, hareketli mütehavvil (a.s.): değişen, değişken

nazarî fizik: teorik fizik

nazariyyât (a.i.): görüşler, teoriler

nısf-ı kutr: yarı çap

nisbet (a.i.): oran

râkid (a.s.): durgun, hareketsiz

rasad (a.i.): gözlem, ölçme

râsıd (a.s.): gözlemci, gözlem yapan

riyâziyyât (a.i.): matematik

saat-i sa'd: uğurlu saat

sâhil-i bahr: deniz kenarı

sath-ı arz: yeryüzü

sehâbiyye (a.i.): bulutluluk, nebülöz

seyyârât (a.i.): gezegenler

sükûnet-i mutlaka: mutlak hareketsizlik

sürat-i azîme: yüksek hız

sürat-i intişâr: yayılma hızı

şakûliyyet (a.s.): dikey nesnelerin yere tam olarak dik olması

şimâl-i garbî: kuzeybatı

şimâl-i şarkî : kuzeydoğu

tarassud (a.i.): gözlem 
tarassudât-ı heyeyye: astronomi gözlemleri

tazyîk (a.i.): basınç

tecârüb-i adîde: basit deneyler

tecrübe-i hikemiyye: fizik deneyi

tefâvüt-i irtifấ ${ }^{6}$ : yükseklik fark1

temevvücât-ı miyâhiyye: suyun dalgalanması

temevvücât-ı ziyâiyye: 1şığın dalgalanması

tenvîr (a.i.): 1şıklandırma, aydınlatma

tûl (a.i.): uzunluk, boy, boylam

tûl-ı mevc: dalga boyu

ubûr (a.i.): gelip geçme ufkıyyen: yatay olarak

ufkî (a.i.): yatay

ulûm-ı riyâziyye ve hikemiyye: matematik ve fizik bilimleri

umk (a.i.): derinlik

Utârid (a.h.i.): Merkür

veter-i kâime: hipotenüs

vezn (a.i.): tartma, tartılma, ağırlık

vezniyyet (a.i.): ağırlık / kütle

ziyâ (a.i.): 1 şk

ziyâ-yı şems: Güneş 1şı̆̆

\section{KISALTMALAR}

$\begin{array}{llll}\text { a. } & \text { : Arapça } & \text { a.zf. } & \text { : Arapça zarf-fiil } \\ \text { a.bs. } & \text { : Arapça birleşik sıfat } & \text { f. } & \text { : Farsça } \\ \text { a.e. } & \text { : Arapça edat } & \text { f.b.i. } & \text { : Farsça birleşik isim } \\ \text { a.f.b.s. } & \text { : Arapça-Farsça birleşik sıfat } & \text { f.i. } & : \text { Farsça isim } \\ \text { a.h.i. } & \text { : Arapça has isim } & \text { f.s. } & : \text { Farsça sıfat } \\ \text { a.i. } & \text { : Arapça isim } & \text { fr. } & : \text { Fransizca } \\ \text { a.s. } & \text { : Arapça sıfat } & & \end{array}$




\section{KAYNAKÇA / BIBLIOGRAPHY}

\section{Basılı Kaynaklar / Printed Sources}

Ademoğlu, Ebru. "Yahya Naci Efendi ve Frrlatılan Cisimlerin Hareketiyle İlgili Eseri 'Risale-i Hikmet-i Tabiiyye." Osmanlı Bilimi Araştırmaları 4, 1(2002): 25-56.

Akbaş, Meltem. "Elektrik Mühendisi Mehmet Refik Fenmen: Osmanlı'dan Cumhuriyet'e Yenilikçi ve Yorulmaz Bir Aydın.” Osmanlı Bilimi Araştırmaları 9, 1-2 (2007-2008): 101-118.

Akbaş, Meltem. "Einstein'ın Görelilik Teorisini Türkiye'ye Tanıtanlar (I): Mehmet Refik Fenmen ve Kerim Erim." Osmanlı Bilimi Araştırmalarl 4, 2 (2003): 49-52.

Çankaya, Levent. “Ali Sedad'ın Kavâid-i Tahavvülât fî Harekâti’z-Zerrât Adlı Eseri, İçeriği ve Termodinamik ile İlgili Bölümlerinin Genel Bir Değerlendirmesi.” Dört Öge 8 (2015): 75-87.

İhsanoğlu, Ekmeleddin. Başhoca İshak Efendi: Türkiye'de Modern Bilimin Öncüsü. Ankara: Kültür Bakanlı̆̆1, 1989.

Kocaman, Meltem. “Einstein'ın Görelilik Kuramı’nın Türkiye'ye Girişi.” Yüksek Lisans tezi, İstanbul Üniversitesi, 2002.

Mehmet Refik [Fenmen]. Aynştayn Nazariyyesi: Mekân, Zaman ve Kütle Mefhumlarının Tebeddülü. İstanbul: Matbaa-i Âmire, 1338 / 1922.

Mehmet Refik [Fenmen]. Aynştay Nazariyyesi: Mekân, Zaman ve Kütle Mefhumlarının Tebeddülü. İstanbul: Matbaa-i Âmire, 1340 / 1924. 